\title{
Working
}

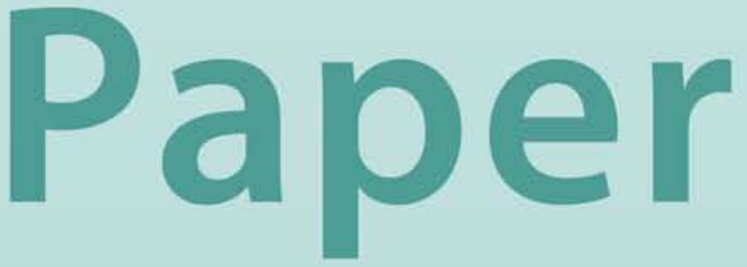


Colonial Origins, Institutions and Economic Performance in the Caribbean:

Guyana and Barbados

Michael DaCosta 


\title{
IMF Working Paper
}

Research

Department

\section{Colonial Origins, Institutions and Economic Performance in the Caribbean: Guyana and Barbados}

\author{
Prepared by Michael DaCosta ${ }^{1}$
}

February 2007

\begin{abstract}
This Working Paper should not be reported as representing the views of the IMF. The views expressed in this Working Paper are those of the author(s) and do not necessarily represent those of the IMF or IMF policy. Working Papers describe research in progress by the author(s) and are published to elicit comments and to further debate.
\end{abstract}

The countries that were once British colonies in the Caribbean share a common language and a colonial history of slavery, dominance of a plantation-based sugar industry, and broadly similar government and administrative traditions. Following independence in the late-1960s economic strategies and performance across the region diverged. However, by the end of the 1980s, in the face of economic collapse Guyana had abandoned its strategy of "cooperative socialism", and its economic policies converged with those generally supported by the IMF and World Bank. Despite this policy convergence and shared colonial origins, economic performance and social indicators in Guyana and Barbados have continued to diverge. The paper explores some of the origins of this divergence, and, in particular, the deep seated factors that derive from the countries' history, geography, and demographics. In Guyana, while the focus on sound macroeconomic policies and donor support has been important, the most pressing requirement for sustained progress is to strengthen domestic institutions and build consensus on the country's future direction.

JEL Classification Numbers: D02, F54, N16, O43, O54

Keywords: Caribbean, Guyana, Barbados, Institutions, Economic History Author's E-Mail Address: mdacosta1@imf.org

\footnotetext{
${ }^{1}$ I am grateful for comments and suggestions from Simon Johnson, Ebrima Faal, Judith Gold, Samuel Itam, Masahiro Nozaki, Rodney Ramcharan, Selwyn Ryan, Arvind Subramanian, and Mary Zephirin, and participants at seminars held at the IMF and the Central Bank of Trinidad and Tobago. I am also grateful to Zhaogang Qiao for excellent research assistance, and Christy Gray, Verona Itam, and Maria Orihuela-Quintanilla for editorial assistance.
} 


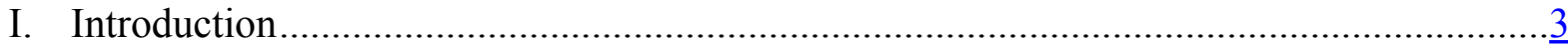

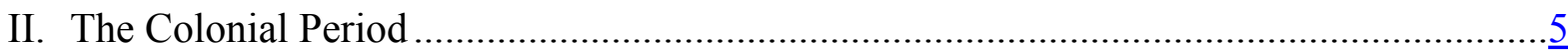

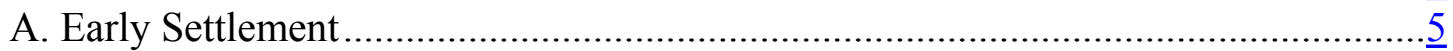

B. The Post-Emancipation Period......................................................................... 11

C. Labor and the Evolution of Political Parties ..................................................... $\frac{15}{17}$

D. A Stock-Taking at the End of the Colonial Period .............................................

III. Divergence in the Post-Independence Period .......................................................

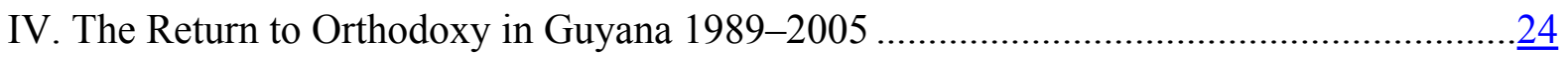

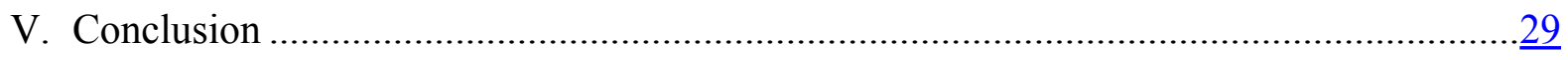

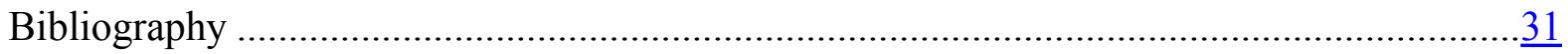

Figures

1. World Sugar Prices (U.S. Cents per pound), 1800-2004 .............................................11

2a. GDP per capita - Guyana, Barbados, and sub-Sahara Africa.....................................

2b. GDP per capita - Guyana and sub-Sahara Africa.....................................................

3. Guyana and Barbados: Post Independence Performance..........................................28

4. Caribbean Region: Income and Institutions......................................................... 28

Boxes

1. Selected Caribbean Countries: British Settlement and Independence............................... $\underline{6}$

2. Barbados and Guyana: Selected Political History ................................................... $\underline{9}$

3. Selected Indicators: End of Colonial Period........................................................

4. Selected Responses of Barbados and Guyana to the Oil Shocks, 1973-74 and 1979-80..... 


\section{INTRODUCTION}

There is growing recognition that economic performance is closely associated with the quality of underlying institutions; i.e., the framework of rules, traditions, and practices that determines how a society functions and is organized. ${ }^{2}$ Much of the literature on this topic has focused on cross-country correlations of income levels and measures of institutional quality, and on the analysis of factors that determine growth or institutional quality, such as initial endowments, colonial experience, income inequality, or democracy. ${ }^{3}$ While there is considerable debate about the relative importance of these factors, causality, and the role of other factors, such as human and social capital or geography, ${ }^{4}$ there is broad agreement that institutional quality is closely linked to economic performance.

The history of the former British colonies in the Caribbean presents opportunities for complementing the existing literature with potentially insightful case studies. ${ }^{5}$ In contrast with other studies that explore institutions and economic performance in a multi-region and or multi-sector setting, or under different colonial regimes, study of the former British Caribbean colonies allows comparisons of institutional development under a single colonial power - with broadly similar government and legal arrangements - and in economies dominated for centuries by a single crop - sugar. Partly as a result of these similarities, toward the end of the colonial period in the 1950s there was some convergence of per capita GDP in these colonies. In addition, there was labor mobility and cultural exchange, as well as calls for political unity based on a sense of a common past and on the recognition of the value of pooling scarce resources. These demands were partially realized in the short-lived West Indian Federation — a political union of 10 governments that lasted from 1958 to $1962 .{ }^{6}$

However, there have also been notable differences in the historical development of the British Caribbean colonies, which influenced their socio-political conditions and economic performance. Barbados, for example, starting in 1639, has had one of the longest

\footnotetext{
${ }^{2}$ In this paper, institutional quality is measured by the indicators developed by Kaufmann, Kraay, and Mastruzzi (2005). The indicators, measuring the "institutions" of voice and accountability, political stability, government effectiveness, regulatory quality, the rule of law, and corruption, are derived by collating perceptions of these variables.

${ }^{3}$ For a sampling of this literature, see Rodrik (2000); Acemoglu, Johnson, and Robinson (2001); Engerman and Sokoloff (2002) and (2005); and Easterly and Levine (2003).

${ }^{4}$ Sachs (2001) and (2003); Glaeser and others (2004).

${ }^{5}$ Country studies that emphasize the role of institutions include Acemoglu, Johnson, and Robinson (2002) on Botswana, and Subramanian and Roy (2001) on Mauritius.

${ }^{6}$ Antigua and Barbuda, Barbados, Dominica, Grenada, Jamaica, Montserrat, St Kitts-Nevis-Anguilla, St. Lucia, St Vincent, and Trinidad and Tobago.
} 
uninterrupted traditions of parliamentary practices as a British colony, and its path to independence in 1966 was smooth. By contrast, Guyana's history includes Dutch colonization until the end of the eighteenth century; fragmentation, i.e. the separate administration and development of its three regions until unification in 1831; and a rocky road to independence, also in 1966 - preceded by the suspension of the constitution by the British government in 1953 and ethnic violence. There were also marked differences between these two colonies in geography, settlement conditions, and land distribution, as well as in labor and immigration policies. As a result, already during the pre-independence period there were manifestations of the effects of these differences on institutions and economic development.

Following independence, countries in the region embarked on divergent development paths. Leaders in Guyana and Jamaica saw economic development as requiring a dominant role for the state, while Barbados and Trinidad and Tobago followed an approach that allowed government intervention in certain sectors as well as foreign investment in others, mainly tourism and energy. By the end of the 1980s and in the face of economic and social collapse, Guyana had abandoned "cooperative socialism" and it adopted adjustment policies that were supported by the IMF and the World Bank. However, a period of rapid growth and social progress during 1990-97 that followed this policy shift — and which coincided in 1992 with the first change in government since the mid-1960s — was followed by the country's relapse into social and political tensions, the absence of sustained dialogue between government and opposition, and a deterioration in key institutions, including the rule of law. As a result, divergences in economic performance, incomes, and social conditions between Barbados and Guyana have remained large.

This paper forms part of efforts to understand the underlying historical factors that help explain the wide divergences in institutions and economic performance in developing countries. It explores why-despite common features of colonial influence and economic structure before independence, as well as a commitment to broadly similar policies since the late-1980s - there have been such wide gaps in the quality of institutions and in income levels in Barbados and Guyana. In other words, why is it that - with both former colonies starting from a per capita income of about US\$150 to US\$200 in the 1950s - the comparable figures in 2004 were US\$10,000 for Barbados and less than US\$1,000 for Guyana, with equally wide differences in measures of institutional quality and human development? ${ }^{7}$ This is a matter of interest not only as a study of institutions and comparative economic performance. Given the commitment of the former Caribbean colonies to convert their common market (CARICOM) into an economic union, persistent gaps in incomes and institutions raise concerns about the preparedness of lagging countries for convergence, and,

\footnotetext{
${ }^{7}$ Based on 2003 data, Barbados was ranked 30 out of a total of 177 countries in the UNDP's measure of human development. Guyana's ranking was 107.
} 
more generally, about the capacity of such countries to contribute to the resource pooling, burden sharing, and other obligations of economic union. So, in the regional context also, greater focus on the underlying institutional and other factors behind economic performance could contribute toward more robust convergence.

The structure of the paper is as follows: Section II describes the period of early settlement through the pre-independence years in Barbados and Guyana, focusing on the influence of geography, demographics, and the evolution of labor and political organizations on the development of institutions. Section III summarizes the divergent economic and sociopolitical trajectory in the post-independence period, while Section IV discusses how, despite the convergence of economic policies since the late-1980s, economic growth faltered in Guyana after 1997, with the country relapsing into political instability, weak rule of law and social tensions. The Conclusion brings together some thoughts on how differences in colonial history, geography, and demographics, as well as other factors, influenced institutions and economic performance. It suggests that the framework for analyzing economic performance and prospects in the region incorporate more systematically discussion and assessment of institutional quality, and sees a stronger role for regional bodies like CARICOM in helping build institutions in member countries that promote consensus building, reduce conflict, and thereby support sustainable economic integration.

\section{The Colonial Period}

\section{A. Early Settlement}

British colonization in the Caribbean can be traced to 1624 when a settlement was established in St. Kitts. This was followed by settlements of Barbados in 1627 and Jamaica in 1655; both remained British colonies without interruption until independence. British settlement of the remainder of the region took place in the late-eighteenth and earlynineteenth centuries (Box 1). In Guyana there is evidence of trading by Dutch and British ships with the indigenous peoples in the late- $16^{\text {th }}$ century, and in the seventeenth century Dutch settlements were established along the Berbice and Essequibo rivers. During the seventeenth and most of the eighteenth centuries the territory that is now Guyana comprised three separately administered regions, Essequibo, Demerara, and Berbice. Through much of the Dutch colonial period, Essequibo and Demerara were administered by the Dutch West India Company, a private company chartered by the Dutch government, while Berbice was controlled by another privately chartered company, the Berbice Association. ${ }^{8}$ The administrative unification of Demerara and Essequibo took place in about 1790, and Berbice was incorporated into those arrangements in 1831.

\footnotetext{
${ }^{8}$ The West India Company's charter expired in 1791, 23 years prior to the British takeover in 1814 (Daly, 1975, p.80).
} 
Box 1. Selected Caribbean Countries: British Settlement and Independence

$\begin{array}{lccc} & \text { Country } & \text { Settlement } & \text { Independence } \\ & \text { St. Kitts } & 1624 & 1983 \\ \text { Barba } & \text { dos } & 1627 & 1966 \\ \text { Jam } & \text { aica } & 1655 & 1962 \\ \text { D } & \text { ominica } & 1763 & 1978 \\ \text { G } & \text { renada } & 1763 & 1974 \\ \text { St. } & \text { Vincent } & 1762 & 1979 \\ \text { Trini } & \text { dad } & 1797 & 1962 \\ \text { G } & \text { uyana } & 1814 & 1966\end{array}$

Sources: Ayearst (1960), Williams (1984).

Sugar, introduced from Hispaniola and Brazil, was the most profitable crop in the colonies. ${ }^{9}$ In the absence of adequate supplies of indigenous labor or indentured workers from Europe, slave labor was initially brought from Brazil, and later, in larger quantities from West Africa. ${ }^{10}$ Cheap labor combined with growing demand and preferential prices for colonial sugar in the British market provided significant returns.

Early settlement as well as the ownership structure of the plantations was influenced by geography. The adjustment of European settlers to life in the colonies was invariably difficult; ${ }^{11}$ however, Barbados was a relatively agreeable location with the advantage of being free of malaria. ${ }^{12}$ By the middle of the seventeenth century, it was the most profitable of the British colonies, with a population of about 30,000 Europeans, of which over 11,000 were landholders. ${ }^{13}$ As a result, between initial settlement and the mid-seventeenth century

\footnotetext{
${ }^{9}$ Other earlier crops included cotton, cocoa, coffee, dyes, and tobacco.

${ }^{10}$ Small indigenous populations were found by the British mainly in Guyana, Belize, and Dominica. By the time of British settlement, indigenous populations in the other islands had probably been exported to other colonies or died through war, work, or disease. See Williams (1984, pp. 95-110) for a summary of the use of indentured labor from Europe in the West Indies.

${ }^{11}$ See Kupperman (1984) for a description of the challenges faced by the early settlers.

${ }^{12}$ The island, however, was not disease free; in the last quarter of the seventeenth century it was affected by a number of epidemics, see Greene (1988, p.155).

${ }^{13}$ Williams (1984, p. 114). He notes that an indicator of Barbados's early prosperity was the inflation of land values. Dunn (1969) estimates that Barbados's exports to England in 1680 were likely higher in value than total exports from all the North American colonies to England.
} 
migration to Barbados was greater than to the largest mainland colonies, Massachusetts and Virginia. ${ }^{14}$ On ownership structure, while there were a few large estates, the small size of the island, high land prices, and the inflow of settlers to Barbados contributed to modest land holdings that averaged no more than 10-20 acres, owned mainly by locally-established companies and resident planters. ${ }^{15}$

By 1629 a framework for local government had been set up in Barbados. Each of the six parishes was administered by elected landowners and had powers to tax and carry out basic municipal functions, such as road maintenance. ${ }^{16}$ In 1639 a parliament (House of Assembly) began to hold sessions. Key decisions were taken in a form of upper house, the Legislative Council, which was controlled by the British governors, but the House of Assembly assumed control over all financial bills.

At the peak of Barbados's prosperity in the second half of the seventeenth century, many planters returned to England after accumulating wealth. At the same time, an improvement in the health of settlers in the early 1700 s led to increased numbers of resident settlers and attention to the demands of settlement, including the education of the children of landowners and the other members of the colonial elite. ${ }^{17}$ Attention to the requirements of settlement was also boosted as falling yields resulting from soil depletion toward the end of the first half of the 1700s discouraged absenteeism and promoted closer personal attention by settlers to the affairs of their estates. ${ }^{18}$ The activities of churches and missionaries led to the establishment of Harrison's Free School in 1733 and a grammar school, Codrington College, in 1745. By 1818 , a school for children of the non-white population had been established and universal education was being discussed. In 1840 the Harrison and Codrington schools were being desegregated. ${ }^{19}$

\footnotetext{
${ }^{14}$ Greenfield (1969, p. 54). Galenson (1985) estimates that through 1670 the rate of outmigration from Barbados was the same as that from some New England towns that have been models of stability in American history. However, the rate for Barbados rose after 1670, reflecting migration to the North American colonies, mainly the Carolinas.

${ }^{15}$ Dunn (1969, p. 12). Even in 1897, only 14 of 440 estates were owned by public companies.

${ }^{16}$ Knight (1990, p. 280).

${ }^{17}$ Greene (1988, p. 155) notes that after 1710 whites in Barbados enjoyed more favorable health conditions than settlers in the rest of the West Indies, the southern mainland of North America, and even in cities such as Boston and Philadelphia.

${ }^{18}$ Average rates of return on total investment fell from in excess of 10 percent during the late seventeenth century to $4-5$ percent in the 1760 s and 1770 s.

${ }^{19}$ Proctor (1980).
} 
Guyana was a relative late-comer to British colonialism-becoming a colony just twenty years before the abolition of slavery, and during a time of falling sugar prices (Figure 1). ${ }^{20}$ Prior to British settlement, the Guyana colonies were essentially outposts of large Dutch trading companies accountable to their shareholders. Early economic activity centered on maximizing trading returns and developing crops for markets in Europe. Nevertheless, to ensure effective administration, by the middle of the eighteenth century, the West India Company moved to formalize administrative arrangements in Essequibo through the establishment of (i) a Council of Policy and Justice comprising company officials and a representative of the settlers, and (ii) a College of Kiezers or Electors ( a form of upper house), responsible for appointing representatives of the settlers to the Council.

Subsequently, the arrangements provided for a third body (the Combined Court), which was responsible for approving all financial matters (Box 2). ${ }^{21}$

The Dutch welcomed traders and settlers from other colonies. By the mid-1700s there was an important inflow of sugar planters and slaves from other British colonies such as Barbados, where soil depletion was beginning to affect yields. At the end of the eighteenth century sugar was entrenched in the Guyana colonies, but as soil exhaustion began to affect also yields in the initial upriver settlements, the movement toward the fertile coast picked up.

Conditions of settlement on the Guyana coast were difficult, and establishing sugar plantations required substantial labor and capital. This reflected the fact that much of the coast lies below sea level at high tide and requires protection against flooding through a complex network of sea walls, dams, and drainage canals that are gated at high tide and opened at low tide to allow the outflow of excess water to the sea. ${ }^{22}$ Additional sources of flooding were (and continue to be) the heavy seasonal rains. ${ }^{23}$ Reflecting these conditions, sugar production in Guyana has been dominated by large plantations owned by British partnerships or companies with ready access to the huge amount of capital needed for drainage and flood control. ${ }^{24}$ Also as a consequence of its geography, much of the country's

\footnotetext{
${ }^{20}$ Williams (1945, p. 361) expresses the view that the history of Guyana would have been different if it had become a British colony in the middle of the eighteenth century. The shortage of labor would have been resolved by the slave trade, and the colony's fertile coast would have attracted large amounts of British capital, outstripping British investment in Barbados or Antigua.

${ }^{21}$ These arrangements were generally retained by the British until 1928.

2290 percent of Guyana's population lives on the fertile but flood-prone Atlantic coast, which represents 4 percent of the country's land area. The remainder of the country consists of forests and savannahs where the main activities are forestry, mining and livestock rearing. The coastal drainage system was introduced by the Dutch settlers.

${ }^{23}$ Coastal rainfall averages about 80 inches a year. The latest in the series of damaging floods occurred in 2005.

${ }^{24}$ Lewis (1968) notes that the ownership structure of the Guyana plantations was characterized by "intense corporate concentration". Williams (1945, p. 363) estimates that establishing a plantation cost $£ 30,000$ to $£ 50,000$, making Guyana "a rich man’s country."
} 


\section{Box 2. Barbados and Guyana: Selected Political History}

\begin{tabular}{|c|c|}
\hline $\begin{array}{l}\text { Barbados } \\
\text { 1639: House of Assembly established. } \\
\text { 1645: Colony divided into } 11 \text { parishes, each sending } 2 \\
\text { representatives to the House of Assembly. } \\
\text { 1652: Beginning of separate sessions of the House and the } \\
\text { Legislative Council (the executive arm of government). } \\
\text { 1831: Right to vote given to free colored men who meet } \\
\text { property requirements. } \\
\text { 1843: First non-white persons elected to the House of } \\
\text { Assembly, one coloured, one black. } \\
\text { 1875-76: Rejection of efforts to establish Crown Colony } \\
\text { government consisting of Barbados and the Windward } \\
\text { Islands. } \\
\text { 1924: Foundation of the Democratic League. } \\
\text { 1935: Grantley Adams elected to the Assembly. } \\
\text { 1938: Formation of the Barbados Progressive League } \\
\text { (the precursor to the Barbados Labour Party). } \\
\text { 1944: Women secure right to vote. } \\
\text { 1946: Elections: Adams--leader of the Barbados Labour } \\
\text { Party, becomes majority party leader. } \\
\text { 1951: Elections-the first under adult suffrage. } \\
\text { 1954: Establishment of the "ministerial” system, a } \\
\text { cabinet, and the office of the Premier. Grantley Adams } \\
\text { appointed first Premier. } \\
\text { 1955: Formation of the Democratic Labour Party led by } \\
\text { Errol Barrow. } \\
\text { 1956: Elections won by the Labour Party. } \\
\text { 1958: Grantley Adams appointed first prime minister of } \\
\text { the West Indies Federation. } \\
\text { 1961: Full self government. } \\
\text { 1961: Elections won by the Democratic Labour Party, } \\
\text { Barrow elected Premier. } \\
\text { 1962: W. I Federation is dissolved. } \\
\text { 1964: Voting age reduced to } 18 . \\
\text { 1966: Independence; Barrow becomes prime minister. } \\
\text { 1971: } 24 \text { single member constituencies established. } \\
\text { 1971: Elections won by the Democratic Labour Party. } \\
\text { 1976: Elections won by the Barbados Labour Party. } \\
\text { 1981: Elections won by the Barbados Labour Party. } \\
\text { 1986: Elections won by the Democratic Labour Party. } \\
\text { 1991: Elections won by the Democratic Labour Party. } \\
\text { 1994: Elections won by the Barbados Labour Party. } \\
\text { 1999: Elections won by the Barbados Labour Party. } \\
\text { 2004: Elections won by the Barbados Labour Party. }\end{array}$ & 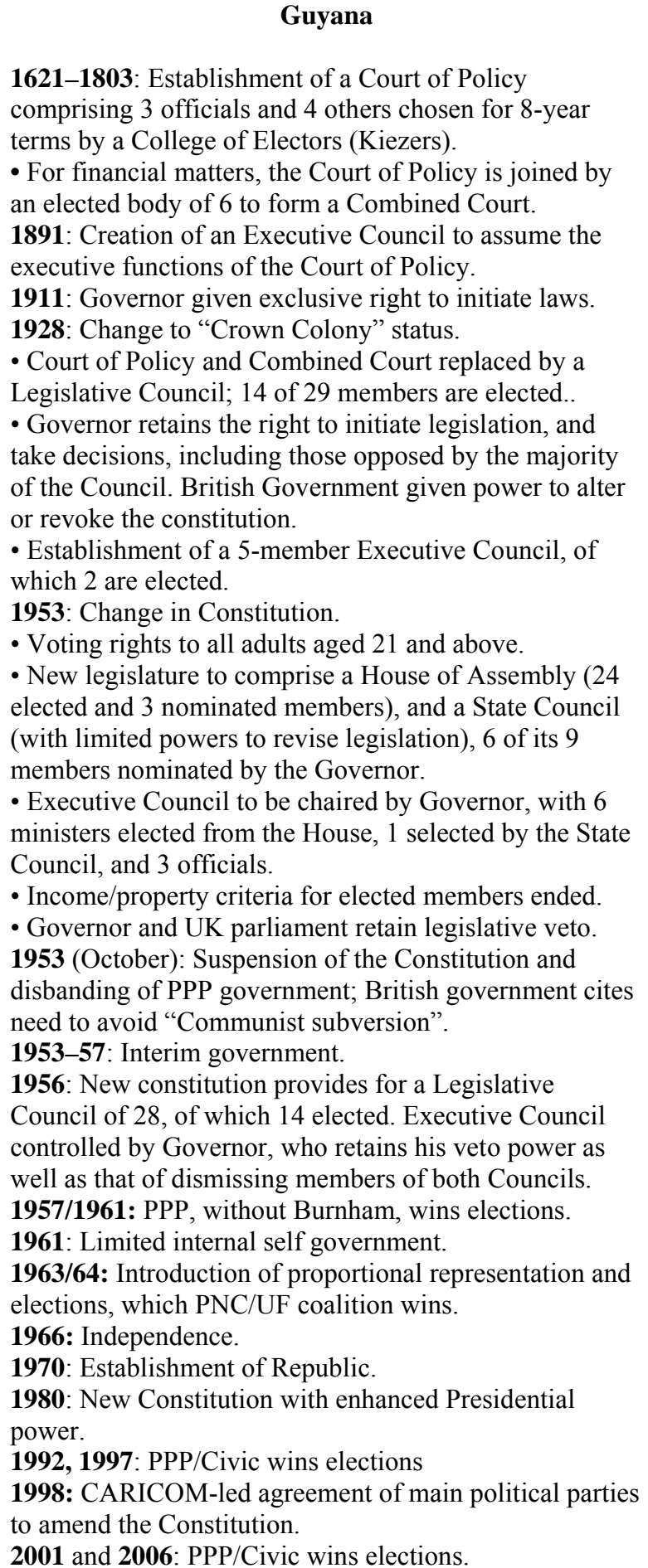 \\
\hline
\end{tabular}

Sources: Ayearst (1960), Glasgow (1970); Lewis (1967); Sires (1954), Tomasek (1959).

http://www.barbadosparliament.com/history.php 
early economic history is a saga of the constant battles of the population - in hot and humid weather-against flooding, and of the social and economic effects of floods on sugar estates and the surrounding villages. ${ }^{25}$

The effects of frequent flooding were compounded by the incidence of disease. Guyana was regarded as among the unhealthiest of the British colonies, and this was reflected in immigrant mortality rates which began to fall significantly only after the establishment of medical centers on sugar estates in the nineteenth century. ${ }^{26}$ Even as late as 1842 and again in 1848, immigration from Madeira was halted because of high mortality rates. Yellow fever appeared in 1852 followed by a threat of cholera in $1853 .{ }^{27}$ As a result of these conditions, owner absenteeism was prevalent - indeed, unlike the situation in Barbados, plantation owners in Guyana comprised mainly groups of shareholders based in London. ${ }^{28}$ In addition, it was difficult to recruit to the Guyana colonies suitable administrators and professionals, such as teachers, and there were frequent shortages of such staff. The sugar plantations dealt with the recruitment difficulties partly by minimizing the length of stay of their managers through frequent rotation. ${ }^{29}$

The British traffic in slaves ended in 1807, and at emancipation in 1834 differences in the institutional development of Barbados and Guyana had emerged. By this time, Barbados had experienced 200 years of a form of representative government. Also, it was a fully occupied territory with high population density, and the colony's compact physical cohesion was complemented by a wide dispersion of local land ownership. Moreover, the objectives of the colonial administration covered both trade and settlement, and attention was placed on the organization of local government and education. ${ }^{30}$ As regards economic structure, as early as the 1730s low yields and falling returns led to a search for options for diversification, including livestock production. ${ }^{31}$ By contrast, for much of its early colonial history, Guyana was essentially a trading outpost, and at emancipation, its three regions had only recently been unified administratively. Also, land ownership was heavily concentrated because of geography and the associated large capital requirements for sugar cultivation, while the colony's adverse settlement conditions led to difficulties in attracting skilled administrators and other professionals.

\footnotetext{
${ }^{25}$ For accounts of the challenges faced by workers in these conditions, see Thomas (1984) and Rodney (1981).

${ }^{26}$ See the chapter by Laurence in Beckles and Shepherd (1996).

${ }^{27}$ Daly (1975, p.249). Efforts to encourage German settlers also ceased because of their high mortality rates.

${ }^{28}$ Lewis (1968, p. 262).

${ }^{29}$ Malaria continues to be one of Guyana's serious health problems, with 27,627 new reported cases in 2003 (24,000 in 2000). Most of these cases were concentrated in the western interior regions (UNDP, 2005).

${ }^{30}$ The emphasis on settlement in Barbados was bolstered by the colony's role as an important British military station, with a strategic position in the eastern Caribbean sea and a permanent force of troops beginning in 1785 .

${ }^{31}$ Greene (1988, p.156).
} 


\section{B. The Post-Emancipation Period}

The post-emancipation period presented considerable challenges for the British Caribbean colonies as they struggled to adjust to rising labor costs and an uncertain labor supply ${ }^{32}$ Other challenges included adjusting to the removal of preferences for West Indian sugar (through the equalization of British import duties on raw sugar in 1854) and to the development of beet sugar in the 1870s, as well as tackling a serious outbreak of sugarcane disease beginning in 1890 . Moreover, after peaking in the mid-1860s, world sugar prices fell continuously through the period of the First World War (Figure 1). As the profitability of the industry in the British colonies declined, inflows of capital dried up and the larger and more efficient producers, such as Cuba, began to dominate global production and exports. The manner in which the British colonies adjusted to these challenges proved crucial in the evolution of economic and social progress in the run-up to independence.

Figure 1: World Price of Sugar (U.S. Cents per pound) 1800 - 2004

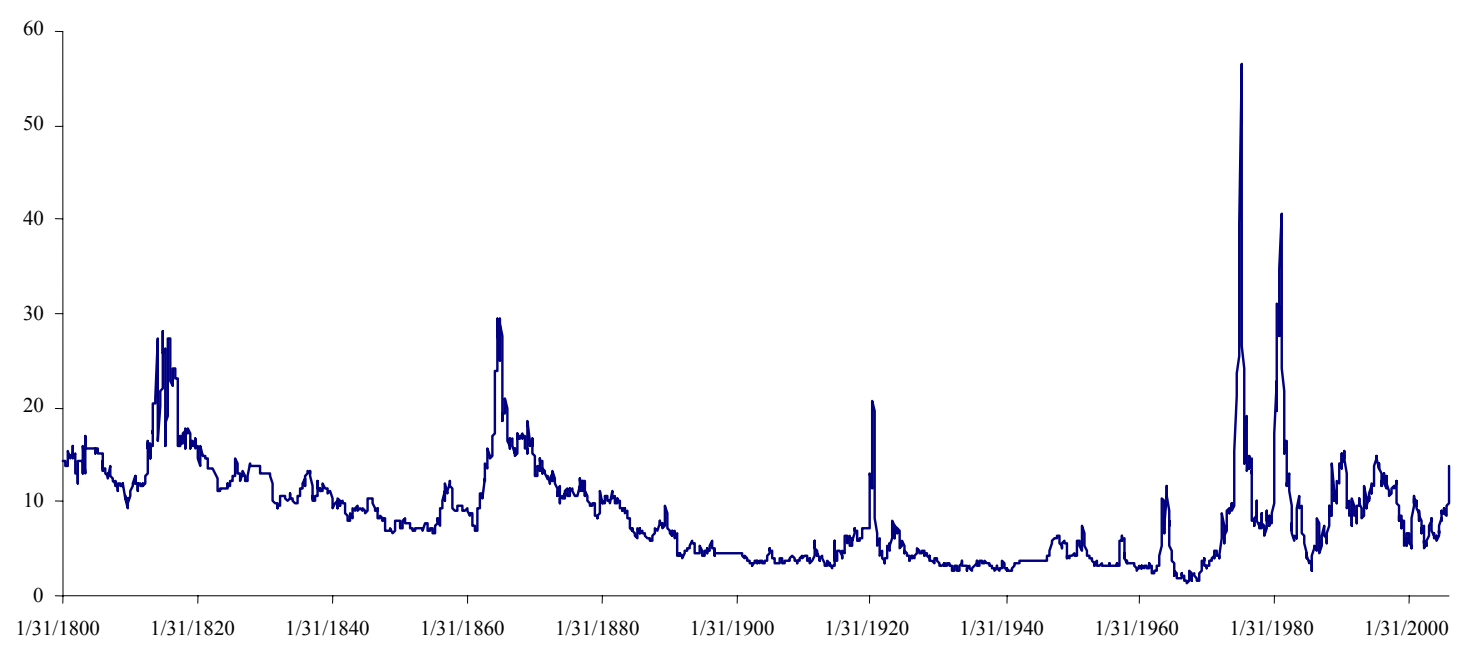

Sources: Global Financial Data (1980 - 1956), and IMF data (1957 - 2004)

Many planters responded to emancipation by collecting their compensation, selling their estates, and returning to England ${ }^{33}$ However, sugar production continued to dominate, and reactions to emancipation were influenced again by the availability of land. In densely populated islands like

\footnotetext{
${ }^{32}$ Sugar production costs rose sharply after emancipation. Shepherd (1929) refers to evidence before the 1848 Committee on Sugar Plantations indicating that in Barbados, costs per hundredweight (112 pounds) rose from 6 shillings to $15 \frac{1}{2}$ shillings.

${ }^{33}$ Total compensation payments in the British Caribbean colonies amounted to almost $£ 16$ million, of which $£ 4$ million was paid in Guyana and $£ 1.7$ million in Barbados (Williams, 1984, p. 332).
} 
Barbados and Antigua, with little available land or jobs outside the plantations, freed slaves continued to rely on the sugar estates for work and housing, and planters benefited from a relatively stable labor supply. However, in colonies with surplus land, many freed slaves moved off the estates to pursue peasant farming - aiming to supplement their incomes by seasonal work on the plantations. Groups of former slaves in Guyana pooled resources to buy land and establish their own village communities, ${ }^{34}$ or they moved into the towns as artisans and laborers. As a result, in the land-surplus colonies sugar exports declined in the immediate post-emancipation period. $^{35}$

Facing an uncertain labor supply, wage demands, and an ample supply of fertile land for expanding sugar production, planters in land-surplus colonies successfully lobbied the colonial administrations to slow the shift away from the plantations, including by raising land prices and the minimum size of plots offered for sale. In Guyana, laws were introduced in the 1850s that prohibited the sale of land to groups of freed slaves and required the partition and taxation of land held by more than ten persons.$^{36}$ Other measures included the eviction of squatters from government lands and the destruction of crops. ${ }^{37}$ These actions, together with the lack of resources for drainage and irrigation, stifled efforts by Guyanese peasants to diversify away from sugar - a process that was underway in Jamaica, for example — and led to their continued reliance on subsistence agriculture and plantation-based labor. ${ }^{38}$

The most far-reaching measure taken by the planters in the larger colonies to ensure a reliable and cheap supply of labor was the importation of indentured workers. Over the period 18381917 the number of indentured workers from India to the British colonies in the Caribbean totaled 430,000 (about 20 percent of the overall colonial population). Most $(238,000)$ went to Guyana, with the remainder to Trinidad (144,000), Jamaica (36,400), and Grenada, St. Lucia, and St. Vincent (an average of about 4,000). ${ }^{39}$ Smaller numbers of indentured workers were also imported from Madeira, China, and other countries, but most of these groups proved unsuited for

\footnotetext{
${ }^{34}$ By 1842, more than 1,000 families of former slaves had bought over 7,000 acres of coastal lands (Knight, 1990, p. 185).

${ }^{35}$ Relative to the pre-emancipation period, 1824-33, annual sugar production in 1839-46 increased in Antigua, Barbados, and St. Kitts, and fell in Guyana and Jamaica. In Trinidad also, production declined after 1838. In Guyana and Trinidad, these declines were reversed after indentureship (Engerman, 1982, p. 196).

${ }^{36}$ Thomas (1984, p. 21).

${ }^{37}$ Williams (1984, pp. 328-9). See also Bourne (1975) and Standing (1979) for descriptions of measures taken by the planters in Guyana to discourage non-sugar agriculture.

${ }^{38}$ See Engerman and Sokoloff (2005) on the role of colonial land policies in contributing to persistent inequality.

${ }^{39}$ Cumper (1960, p. 27). By 1911, indentured Indian workers in Guyana outnumbered freed slaves and constituted about 40 percent of the population.
} 
work on the plantations, and many Portuguese, for example, shifted to the importation and distribution business. ${ }^{40}$

Indentureship led to low labor costs, improved prospects for the sugar industry, and significant new investment in the industry in Guyana and Trinidad during the second half of the nineteenth century. In Guyana, investment centered on steam-powered factories and better irrigation and transportation systems. By the early-1880s the colony dominated the British West Indian sugar industry and its estates were known for their “.... economy and latest manufacturing appliances". ${ }^{41}$ However, the social costs of this achievement were high and conditions faced by the indentured workers were harsh. In exchange for a small wage, poor housing, and rudimentary medical attention, they were obliged to remain for a period of five years on the estates to which they were contracted. By 1910, the terms of indenture were five years' work on a designated estate followed by five years of residence in the colony, after which workers were entitled to a return passage to India. ${ }^{42}$ Workdays were 12 hours long and disciplinary measures included fines and arrest for completing tasks in a manner judged unsatisfactory, and for venturing more than two miles away from estates during working hours. ${ }^{43}$ Such infractions severely reduced workers' incomes and prospects for an early return to India, and the penalties triggered numerous protests. $^{44}$

Tensions developed between the new arrivals and freed slaves - centered on jobs and wages in an environment in which work conditions of the indentured workers combined with differences in language and culture created barriers between the two communities. ${ }^{45}$ In addition, indentureship occurred at a time when the supply of labor in Guyana appeared to be adequate, as evidenced by the groups of former slaves moving from estate to estate seeking work and by a steady inflow of Barbadian workers that coincided with their migration in the second half of the 1800s and the early-1900s to the Panama Canal, the banana estates of Costa Rica, and the

\footnotetext{
${ }^{40}$ Arrivals from Portugal/Madeira amounted to 40,000 during 1835-82 (Mintz, 1984). Small numbers of workers were also brought in from Germany, Malta, Brazil, Mauritius, and West Africa (Thomas, 1984).

${ }^{41}$ See chapter by Lodbell in Beckles and Shepherd (1996).

${ }^{42}$ By 1924, about a quarter of indentured workers who arrived in the British West Indian colonies had returned to India. (Williams, 1984, p. 352).

${ }^{43}$ Jagan (1972, p. 41).

${ }^{44}$ During 1886-89 there were about 100 labor disturbances involving indentured workers in Guyana (Daly, 1975).

45 The wage rate for indentured workers was about half that prevailing for free labor (Thomas, 1984, p. 21). Rodney (1981) makes the point that care should be taken in viewing the tensions among groups of workers as based only on race. Former slaves viewed with anxiety all new arrivals as potential competitors for limited work on the estates, and there were also disputes over labor and land among groups of former slaves. Jagan notes that indentured workers were used as strike breakers not only against freed slaves but also "freed" indentured workers who demanded higher wages.
} 
United States. ${ }^{46}$ The sense that the labor supply was adequate bolstered the view among former slaves that the importation of indentured workers was aimed at breaking strikes and lowering wages. ${ }^{47}$ One of the largest planters, Sandbach Parker, observed: "...so long as an estate has a large Coolie gang, Creoles must give way in prices asked or see the work done by indentured labourers-and this is a strong reason why the number of Coolies on estates must not be reduced .......". 48

Tensions also stemmed from the use of government revenue (mainly import taxes and fees) to help finance the importation of indentured workers at a time when social expenditures were low. ${ }^{49}$ Another source of friction were government policies for settling indentured workers who had completed their contracts. As part of efforts to keep these workers on the estates and reduce the costs of repatriation, beginning in 1871 and continuing through the end of the indentureship scheme in 1917, the government allocated land to indentured workers for housing and crops and allowed them to purchase land, including land repossessed from freed slaves on account of unpaid taxes. ${ }^{50}$ Much of this land was used for rice cultivation. By 1890 rice was an important crop and exports began in the first decade of the $20^{\text {th }}$ century. Tensions were not limited to African and Indian workers. There were also protests in the late-1800s involving freed slaves and Portuguese shopkeepers over complaints of high prices of basic goods.

In summary, post-emancipation labor and land distribution policies in Guyana together with the colony's geography helped constrain the development of a diversified agricultural sector and landholding by small farmers. ${ }^{51}$ Moreover, these policies created the conditions that contributed to tensions between freed slaves and other workers on basic issues such as jobs, wages, land, and the allocation of tax revenue. Also, they helped consolidate the process by which the Indian population concentrated in rural communities near to sugar estates, while the former slaves formed the majority in urban centers. In assessing the condition of former indentured workers, a representative of the Indian government visiting Guyana in 1925 observed that the prosperity

\footnotetext{
${ }^{46}$ There were 1,075 arrivals per year of Barbadian workers in Guyana during 1835-46 (Rodney, 1981, p. 48).

${ }^{47}$ A strike in 1847 by freed slaves against planters' efforts to lower wages failed because indentured laborers continued working (Daly, 1975).

${ }^{48}$ Rodney (1981, p. 38).

${ }^{49}$ The burden of import taxes fell heavily on freed slaves. In Guyana, public expenditure on immigration in 1842 was equivalent to 17 percent of total expenditure, the same ratio as that spent on health, public works, education, and welfare combined (Moohr, 1972, p. 353).

${ }^{50}$ By 1880 unindentured Indian workers outnumbered indentured workers on the sugar estates. Indentureship ended following the intervention of the Indian government in response to complaints about the treatment of workers. By 1920 the last indenture contracts had been completed (Rodney, 1981, p. 34).

${ }^{51}$ For an elaboration of this point see Thomas (1984) and Rodney (1981).
} 
of the Indians was not as high as in Trinidad or Mauritius, where Indians owned more land. He attributed much of this to the difficult geography and the costs of drainage and irrigation. ${ }^{52}$

\section{Labor and the Evolution of Political Parties}

Falling sugar prices in the second half of the nineteenth and most of the first half of the twentieth century led to a consolidation of the industry in the British colonies. This involved the closure of unprofitable estates, including in Guyana, one of the most efficient producers. ${ }^{53}$ In these conditions, indications of surplus labor were evident in low or falling wages and rising unemployment. Beginning in the late-1800s there were growing labor protests, the formation of workers' groups, and the transformation of these groups into national political parties. Large and well organized labor unions were established in Guyana and Trinidad and Tobago in 1919-20, and unrest continued through the 1930s, exacerbated by the effects of the global recession and manifested in a wave of strikes. Differences in the evolution of labor and political organizations in Barbados and Guyana played an important role in the development of these countries' institutions.

In Barbados, the comparative stability of the immediate post-emancipation period was followed by severe adjustments as wages and employment fell while food prices rose. Economic hardship was exacerbated by poor social conditions and the absence of worker protection, and these factors helped fuel riots in 1863 and $1876 .{ }^{54}$ With the option of shifting into peasant farming constrained by the shortage of land, beginning in the 1870s emigration emerged as an important alternative for agricultural workers. ${ }^{55}$ By the 1940s the Barbados Labour Union and its political arm, the Barbados Labour Party were beginning to put in place measures to improve work and social conditions, including a guaranteed minimum daily wage for sugar workers, a reduction in taxes, and access to credit facilities that allowed workers to buy homes freehold and reduce their dependence on plantation housing. Other measures covered hospital improvements, the introduction of the Provident Fund - an insurance mechanism for sick or disabled workers and their families, and holiday with pay. Labor union members were also appointed to boards of public institutions and received training and education through union-sponsored classes. ${ }^{56}$

\footnotetext{
${ }^{52}$ Daly (1975, p. 285).

${ }^{53}$ The number of sugar estates or plantations in Guyana fell from 308 in 1838 to 105 in 1884 and 46 in 1904 (Standing, 1979). By the late-1950s, one British company, Booker McConnell, controlled the sugar industry, owning 12 of the 17 plantations, with an average plantation size of 7,000 acres (Tomasek, 1959, p. 394).

${ }^{54}$ See the chapter by Craton in Beckles and Shepherd (1996).

${ }^{55}$ Emigration continued through the early-1900s, boosted by demand for workers in the U.S. and the Panama Canal. Remittances to Barbados during 1906-1910 averaged over $£ 65,000$ a year, which helped finance the purchase of housing lots (U.K. Colonial Office, 1965, p. 116).

${ }^{56}$ Lewis (1968, pp. 235-242).
} 
On the political front, the report of the Moyne Commission ${ }^{57}$ helped advance greater representation in government. Barbados was the only colony that had been successful in maintaining uninterrupted representative government under British rule, with an elected House of Assembly and an appointed Legislative Council. ${ }^{58}$ In the first elections following the introduction of universal voting rights in 1951, the leader of the Barbados Labour Party, Grantley Adams, became premier. By 1954 elected ministers in Barbados formed a cabinet, and in the early-1960s the government was given full control over internal matters, including the civil service, the judiciary, and legal affairs.

In Guyana there were promising initial efforts to forge labor and political unity in the campaign toward independence. Those efforts included the mobilization of urban laborers as well as Indian sugar workers by the British Guiana Labor Union (BGLU). In addition, two political leaders (Cheddi Jagan - an Indian dentist, and Forbes Burnham, an African lawyer) joined forces in a new labor union, the Guiana Industrial Workers' Union (GIWU) and a political party, the People's Progressive Party (PPP). Guyana's new constitution in 1953 provided for an elected House of Assembly, with a policymaking body, the Executive Council, comprising ten members (of which six would be elected by the House of Assembly) and chaired by the governor. However, in sharp contrast to the arrangements in Barbados, the governor retained the right to veto all legislation and to adopt measures, including those rejected by the legislature.

Shortly after the PPP victory in 1953 elections, a crisis erupted that led to the suspension of the constitution and the dismissal of the government. A key factor was the grave concern in the United Kingdom and the United States - in the context of the global tensions of that periodabout Jagan's support for Marxism and his ties to the Soviet Union and Cuba. At home, sugar producers expressed fears that the PPP was attempting to push through legislation that would install the GIWU as the sole bargaining agent for sugar workers. Geopolitical concerns and domestic opposition culminated in the arrival of British troops, the suspension of the constitution in October 1953, and the imposition of an interim government. ${ }^{59}$ Toward the end of the term of the interim government the colonial administration changed the constitution to replace the elected majority in the legislature with an equal number of elected and appointed members. This reversal of the movement toward representative government aimed at reducing the risks of a likely PPP victory in subsequent elections.

\footnotetext{
${ }^{57}$ West India Royal Commission (1945). The Commission was set up to enquire into the reasons behind the labor unrest in the colonies in the 1930s.

${ }^{58}$ The other colonies were administered as "Crown Colonies", which implied almost full control of government arrangements by the governors.

${ }^{59}$ The British government cited the risk of violence by the PPP as one of the reasons for sending in the army.
} 
Political unity did not survive the constitutional crisis and Burnham split from the PPP in 1955 to form his own party, the People's National Congress (PNC). Both elections following the split (in 1957 and 1961) were won by the PPP, however, already in the 1957 election, alignments with political parties along racial lines were evident. ${ }^{60}$ Tensions worsened after the 1961 election, as labor (other than the unions in the sugar industry, which supported Jagan) and business interests united to oppose a budget that proposed higher taxes on incomes and imports. More intense protests took place in 1963 against labor legislation that would have obliged employers to recognize the union gaining the highest number of votes in a secret ballot. ${ }^{61}$ These protestsincluding a prolonged strike by opposition-supported unions with external support that paralyzed the country - and the tensions they generated erupted in widespread racial violence in $1964 .^{62}$ Despite the violence, the colonial administration proceeded with preparations for independence, and decided that in the pre-independence elections in December 1964 the electoral system and the allocation of parliamentary seats would be based on proportional representation instead of on constituencies. Following the elections, a coalition of the PNC and a small conservative party took power, marking the start of an uninterrupted period of 28 years of government by the PNC.

\section{A Stock-Taking at the End of the Colonial Period}

At the end of the colonial period, sugar remained the dominant industry in the Caribbean region. However, divergences in economic and social conditions and in basic institutions - which had been held in check by colonial policies and financial support-increasingly became apparent as the colonial presence diminished.

- GDP per capita in the mid-1950s (about US\$180-\$190) was broadly similar in Barbados and Guyana. However, by the mid-1960s the figure for Barbados had risen to US\$469, while that for Guyana stood at US\$295 (Box 3).

- $\quad$ Fiscal policy during the pre-independence period also had an important bearing on the nurturing of institutions. Barbados maintained a record of balanced budgets or small deficits, and unlike other Caribbean colonies, it did not rely on annual budget support grants from the United Kingdom. ${ }^{63}$ However, Guyana had incurred persistent deficits as a result of a weak revenue base combined with the demands for sea defense, water supply, and drainage. At the end of the colonial period Guyana's debt was the highest in the region; it spent more resources on

\footnotetext{
${ }^{60}$ Tomasek (1959, p. 410).

${ }^{61}$ The labor legislation would have paved the way for the recognition of a PPP-backed union in the sugar industry. The umbrella trade union organization referred to the legislation as "a blue-print for the end of trade union freedom in British Guiana” (Daly, 1975, p. 305).

${ }^{62} 176$ people were killed, 920 injured, 1,400 homes were destroyed by fire, and about 15,000 people ( 2 percent of the population) moved their homes to villages dominated by their own ethnic group (Daly, 1975, pp. 306-7).

${ }^{63}$ http://www. barbadosparliament.
} 
debt service and less than most countries on education and social services; and was more dependent on grants from the United Kingdom ${ }^{64}$

- $\quad$ On social indicators, Guyana shared with Barbados a high literacy rate (about 83 percent), despite the former's shortages of trained teachers and overcrowding in schools. However, enrollment rates for elementary schools were lower in Guyana than in Barbados, Jamaica and Trinidad and Tobago. By 1962 Barbados had introduced free secondary education, and its expenditure on public health reached 18 percent of total expenditure in 1962-63. ${ }^{65}$

- $\quad$ Barbados continued to consolidate its political stability and build a national consensus on economic and social policies. The establishment of the Democratic Labour Party in 1955 did not lead to increased political tensions, as that party adopted broadly the same social democratic principles as the Barbados Labour Party. In Guyana, as noted, initial efforts at political unity across ethnic lines succumbed to the emergence of deep differences between the two main political leaders and the alignment of politics along ethnic divisions. These developments led to disillusionment by many about the future direction of the society and to large scale emigration.

- Labor relations in Barbados reflected a broadly united labor movement and close collaboration between unions and the main political parties on an agenda for social and economic progress. Persistent unemployment pressures were eased partly through emigration during the early-1960s to Canada, the United Kingdom and the United States, and the U.S. Virgin Islands. By contrast, the labor movement in Guyana was divided into two broad factions. One was based in the coastal/agricultural sector, dominated by Indian workers and supportive of Mr. Jagan's party, and the other was based in the urban/mining sectors dominated by African workers and allied to Mr. Burnham's party.

- $\quad$ Some diversification was achieved in Guyana through the development of the bauxite industry with foreign investment. However, the country remained highly dependent on two crops (sugar and rice) which were not internationally competitive and further entrenched the country's economic base on the flood-prone coastal areas. A single British multinational, the Booker Group, controlled the sugar industry and much of the country's agricultural land. ${ }^{66}$ Efforts to promote a manufacturing sector through credit and tax incentives were stifled by poor infrastructure, the tense political climate during the 1950s, uncertainty about the PPP's attitudes

\footnotetext{
${ }^{64}$ See Cumper (1960, pp. 206-211). The Moyne Commission Report (p.67) noted that in 1938 Guyana's debt totaled $£ 4,395,000$ - the highest in the British colonies, equivalent to $£ 13$ per head — and that debt service accounted for 21 percent of total expenditure. Equivalent figures for Barbados were $£ 377,000$, 22 per head, and 5 percent. Referencing data for 1944, Hammond (1946) estimates that Guyana's expenditure on education as a percentage of tax revenue (2.2 percent) was significantly lower than that of Barbados, Jamaica, and Trinidad and Tobago (14.5, 16.5, and 7.1 percent, respectively).

${ }^{65}$ U.K. Colonial Office (1965).

${ }^{66}$ Lewis (1968, p. 265) mentions a claim by the Booker Group that it controlled directly and indirectly the lives of about 80 percent of the population.
} 
to the private sector and foreign investment, and the ethnic violence in the early-1960s. In Barbados diversification was faster and more successful, partly because sugar estates were smaller and less efficient and the investment climate was favorable. In particular, the new tourism industry developed rapidly with the introduction of large scale jet travel in the mid$1950 \mathrm{~s}$, and helped stimulate the development of a domestic services industry. ${ }^{67}$ Tourism also helped promote the development of a middle class that supported openness and a strategy of developing good relations with markets in Europe and the U.S. The favorable investment climate and incentive legislation helped develop also during the early-1960s an important manufacturing sector in Barbados employing about 12 percent of the labor force. ${ }^{68}$

At the end of the colonial period, therefore, Barbados was generally better prepared to meet the challenges of independence and faced more favorable long term prospects. Much of this advantage appeared to be due to the quality of its institutions, including political stability and the rule of law. Assessing the country's situation on the eve of independence, the Leader of the House of Assembly noted that Barbados in 1963 already had the following prerequisites for independence: (i) a sense of national unity; (ii) political experience based on democratic foundations; (iii) a seasoned civil service that provided administrative capacity; and (iv) a sound economy ${ }^{69}$ Just prior to independence in 1966, the country's first prime minister, Errol Barrow, observed that “... the overall picture gives reason for confidence and perhaps optimism."70 At about the same time, Guyana was recovering from the ethnic conflict and the collapse of the rule of law of the early-1960s, its government institutions were weak, and there was little of the confidence and optimism that prevailed in Barbados. ${ }^{71}$ Also, there was no consensus on economic policy and the labor movement was divided. In an early assessment of the effect of emigration on key institutions, a report of the Guyana government in 1966 complained about shortages of professional and skilled labor. ${ }^{72}$

\footnotetext{
${ }^{67}$ Tourist arrivals almost doubled to about 68,000 between 1960 and 1965, and generated earnings of BWI\$26 million in 1965 (55 percent of merchandise exports).

${ }^{68}$ U.K. Colonial Office (1965). By 1963 there were 34 manufacturing firms in Barbados.

${ }^{69}$ Lewis (1968, p. 256).

${ }^{70}$ Government of Barbados (1966).

${ }^{71}$ Lewis (1968) observes that during the pre-independence period, Booker's organized and administered much of the health and social services on the sugar estates with the result that government administrators and the public in rural areas developed little experience of the functioning of government.

${ }^{72}$ Government of Guyana (1966)
} 


\section{Box 3. Selected Indicators at End of the Colonial Period ${ }^{1}$}

Population, output, and prices

Populatio

Total land area (sq. km)

Population density (per sq. km)

GDP (millions of U.S. dollars) local

GDP per capita (U.S dollars)

Real GDP growth: Annual average, 1961-65

Sugar as percent of GDP

Inflation rate (average 1961-65)

\section{Labor force and employment}

Unemployment rate

Number of labor disputes (average 1961-65)

\section{Social indicators}

Death rate (per thousand)

Reports of crime (average 1961-65)

Ratio of population per crime

Education and social expenditure

in percent of total expenditure ${ }^{2}$

\section{Barbados Guyana}

$244 \quad 622$

$430 \quad 214,969$

$570 \quad 3$

$115 \quad 181$

$469 \quad 295$

$4.1 \quad 2.9$

$19.9 \quad 14.4$

$2.0 \quad 1.9$

$13.0 \quad 20.9$

$4 \quad 74$

$\begin{array}{lr}7.8 & 8.2\end{array}$

$4,950 \quad 91,434$

49:1 $7: 1$

$43 \quad 27$

Sources: Barbados: Abstract of Statistics 1965; Guyana: Annual Statistical Abstract 1970; World Development Indicators, and author's estimates.

${ }^{1}$ Data refer to 1965 , except otherwise indicated.

${ }^{2}$ See Cumper (1960); data refer to 1953-54.

\section{Divergence in the Post-Independence Period}

In the period immediately following independence two broad strategies for economic development emerged in the former British Caribbean colonies. One strategy favored industrialization through foreign investment that would lead to transfers of technology and finance, while the other urged a thorough transformation of Caribbean economies, including through nationalization of foreign companies; import substitution and changing the pattern of tastes; and developing industries based on domestic resources. ${ }^{73}$

Barbados and Trinidad and Tobago adopted a strategy of encouraging foreign investment in the tourism and oil and gas sectors while at the same time providing tax and other incentives to

\footnotetext{
${ }^{73}$ For a summary of the debate, see Worrell (1993), and for a sample of views supporting the latter strategy, see the chapters by Best and Levitt, and Demas, in Beckford (1975).
} 
promote manufacturing..$^{74}$ Barbados's strategy was supported by a national consensus that openness was the most appropriate option for promoting growth and social progress, given the country's small size and reliance on trade and tourism. Moreover, there was little anti-foreigninvestment sentiment since, as noted, many plantations during the colonial period were owned by Barbadian entities. ${ }^{75}$ A key anchor for this strategy was the consensus on the need to preserve the exchange rate peg by maintaining prudent fiscal policies, and an early manifestation of this prudence was the setting aside of much of the 1973-74 sugar price windfall in a fund for housing. ${ }^{76}$

The Guyana government opted for a strategy of "cooperative socialism," some key elements of which were:

- $\quad$ state control of most of the economy (including the nationalization of the sugar and bauxite industries and most foreign banks; centralized allocation of bank credit, foreign exchange, and imports; and price controls);

- the development of a state-owned manufacturing sector;

- $\quad$ state control of education; and

- the creation of an "executive presidency" with broad powers, including immunity from prosecution and authority to dismiss parliament. ${ }^{77}$

Initially, the effects of these policies on the Guyana economy were masked by the commodity boom of 1974-75. However, as sugar prices fell sharply in 1976 signs of crisis emerged. In January 1978, the government turned to the IMF for financial assistance and loans were approved in 1979-80. Barbados experienced similar sugar price shocks, and a comparison of the responses of these two countries to these first post-independence crises sheds important light on the differences in policy approach as well as in political and institutional settings at the time (Box 4). ${ }^{78}$

\footnotetext{
${ }^{74}$ Williams (1984, pp. 511-512) describes the economic strategy adopted in Trinidad and Tobago in 1969 as involving foreign investment and trade, increasing control over the commanding heights of the economy, promoting racial harmony and social equity, and developing a national and cultural identity.

${ }^{75}$ Griffith (2002, p. 87).

${ }^{76}$ Worrell (1993, p. 196).

${ }^{77}$ Payne (1981, p. 62).

${ }^{78}$ See Worrell (1987) for a detailed assessment of Barbados's response to the two commodity shocks.
} 
An assessment of the responses to the crises indicates that Barbados's was characterized by a consensus on policies backed by an institutional capacity to implement them, a greater propensity to save, and access to financial markets. Partly as a result of its handling of these shocks, and also because of its diversified export base the country was able to maintain stability, recover from the recession in the first half of the 1980s, and achieve a recovery in the second half of the decade. ${ }^{79}$ Guyana's decision to use the sugar windfall to press ahead with the nationalization of the sugar industry in 1976 deprived the country of an important pool of savings. Moreover, the nationalization of sugar, occurring shortly after that of the bauxite industry in 1971, placed an unsupportable burden on the country's limited technical capacity and weak institutions in the context of heavy emigration of skills. ${ }^{80}$ These factors, exacerbated by political tensions, resulted in Guyana's emergence from the first commodity boom with its international reserves exhausted. The response to this - the introduction of controls over imports and foreign exchange-led to severe distortions, promoted rent seeking, and disrupted economic activity. ${ }^{81}$

Following the 1973-74 crisis and throughout the late-1970s and early-1980s Guyana's political climate was marked by continued instability, the absence of dialogue and consensus-seeking, and a further weakening of key institutions, such as the rule of law. Production of all the major commodities declined sharply; public utilities and social services barely functioned; and real wages fell sharply (by 40 percent between 1976 and 1986). During the 1976-88 period, real GDP per head fell by 31 percent, inflation soared eightfold, foreign exchange reserves dwindled, and government debt rose from 31 percent of GDP to 475 percent. In 1984, real GDP fell to its lowest level since $1955,{ }^{82}$ and the size of the informal economy was estimated at 40 percent of the formal economy. ${ }^{83}$ Indeed, for most of the 1980s and the first half of the 1990s GDP per capita in U.S. dollars was lower than in sub-Saharan Africa (Figure 2). Toward the end of the 1980 s, the country physical infrastructure - including the critical drainage and sea defense

\footnotetext{
${ }^{79}$ Barbados's capacity for consensus building in the face of crisis was demonstrated again during the 1991/92 balance of payments crisis. Much of the success of the response to that crisis (which included Fund financing) was due to wage protocols (tripartite agreements of the government, labor, and the private sector), which required an across-the-board commitment to overriding national goals, supported by strong institutions and capacity. The protocols also provided a mechanism for accommodating special interests such as labor unions, and providing voice to non-government groups. See Downes and Nurse (2004) for an assessment of the protocols.

${ }^{80}$ On the heavy administrative and managerial burden of overseeing the wide range of public sector activities in Guyana, see Blackman (1989) and Worrell (1987).

${ }^{81}$ This result is consistent with work by Rodrik and others, which shows that adjustment to shocks is worse in countries with conflict and poor institutions for conflict management.

${ }^{82}$ Egoume-Bossogo, Faal, Nallari, and Weisman (2003).

${ }^{83}$ Faal (2003).
} 


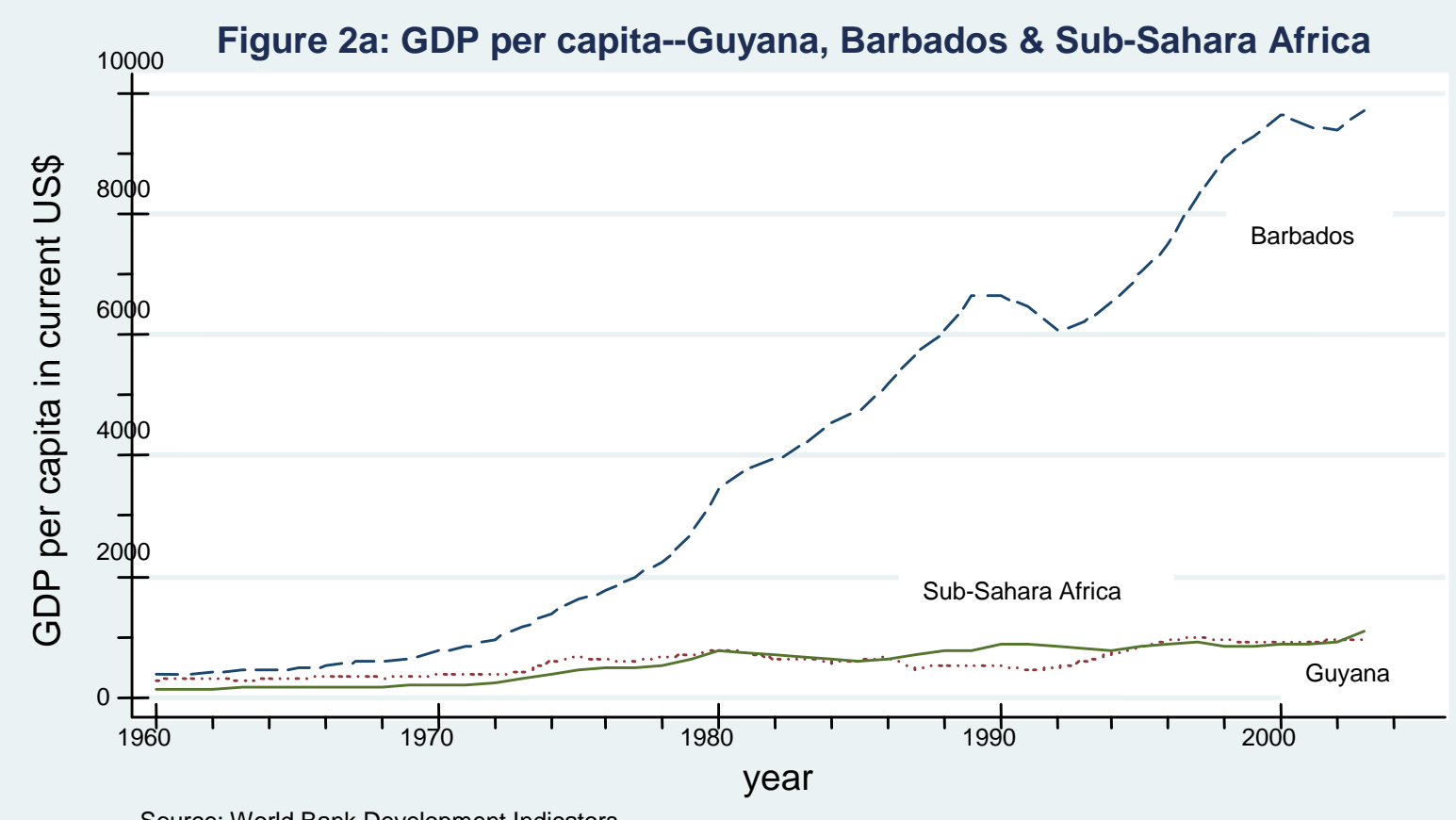

Source: World Bank Development Indicators

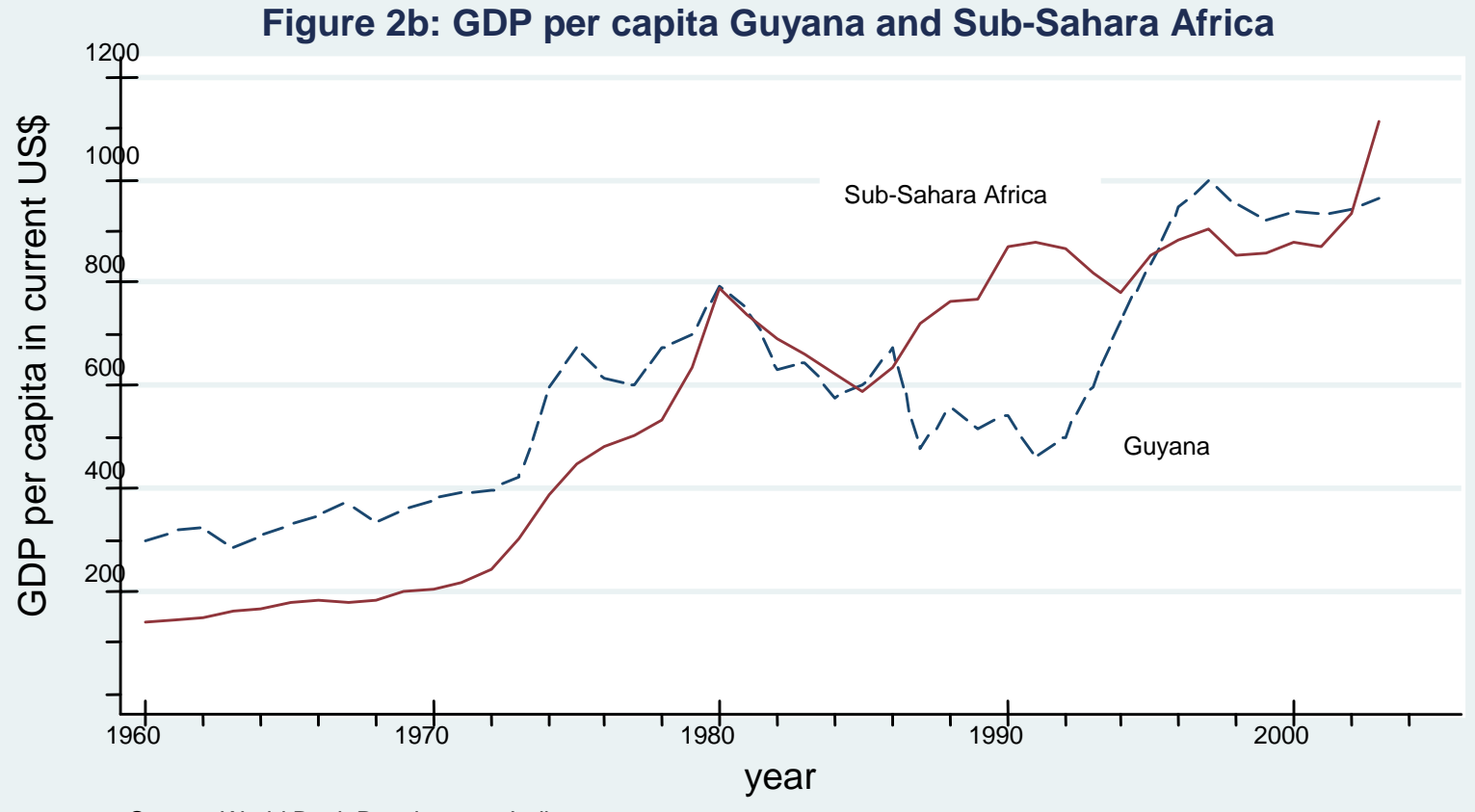

Source: World Bank Development Indicators 
infrastructure - deteriorated considerably, and indicators of health and education, and overall social conditions worsened. Among the most visible and damaging effects of the policies during this period were those associated with the loss of human resources and skills through migration. ${ }^{84}$

By 1986, at about the time when the Barbados economy was entering a period of recovery, the Guyana economy had collapsed. The main proximate factors responsible for the crisis included the choice of economic strategy that led to the too-rapid expansion of the public sector relative to the available skills and managerial capacity, and its financing through a rapid buildup of debt; and strikes in the key sugar and bauxite industries that led to shortages of spare parts and inputs. Also important were weaknesses in policy formulation and monitoring. However, the deepseated factors behind the crisis were weak governance institutions that provided little restraint on the executive; a persistent instability in the political system marked by a lack of trust and dialogue among political and labor groups that precluded consensus building on national policies; and a breakdown in the rule of law.

\section{The RETURN TO ORTHODOXY IN GUYANA 1989-2005}

Tentative steps toward abandoning Guyana's economic strategy began following the death of President Burnham in 1985. However, a full fledged shift to a market-based strategy was marked by the launch of the Economic Recovery Programme (ERP) in 1989. The ERP covered macroeconomic stabilization - through exchange rate adjustment, price and trade liberalization, and public expenditure control - as well as reforms including the reversal of the nationalizations undertaken in the 1970 s - particularly in the sugar and bauxite industries. ${ }^{85}$ However, at an early stage, the ERP was stalled by strikes by the opposition-supported unions in the sugar industry. ${ }^{86}$ Beginning in 1990, when Guyana regained its borrowing rights in the IMF, the recovery effort was supported by a series of loans from the Fund and the World Bank. ${ }^{87}$ A main objective of the programs was to promote export-led growth through increased public investment, higher public sector saving, and the settling of arrears with creditors. Growth would be supported through a reform agenda aimed at public sector reforms and privatization.

\footnotetext{
${ }^{84}$ During 1965-2000, 89 percent of the Guyana labor force educated at the tertiary level migrated to OECD countries. The ratio for Barbados was 63 percent and the average for the Caribbean region was 70 percent, see Mishra (2006).

${ }^{85}$ For details of the ERP and its achievements, see Egoumé-Bossogo, Faal, Nallari, and Weisman (2003).

${ }^{86}$ Data from Guyana's Draft National Development Strategy (1997) and the ILO show that during 1985-94 the number of strikes averaged 393 per year, compared with 8 in Barbados and 19 in Trinidad and Tobago.

${ }^{87}$ Three loans under the Fund's Poverty Reduction and Growth Facility (PRGF) and a Stand-By arrangement were completed over the period 1990-2002, and a further PRGF loan was signed in 2002. In the 17-year period 19902006, the IMF disbursed loans in all but one year. Over that period, disbursements totaled SDR255 million, while repayments, charges, and interest totaled SDR364 million. http://www.imf.org/external/np/tre/tad/extrans1.cfm?
} 
The broad objectives of the ERP were maintained by the new PPP administration that took office following the party's victory in the 1992 election. ${ }^{88}$ The first years of that administration were marked by progress in economic growth and social conditions: ${ }^{89}$

- $\quad$ Macroeconomic stabilization was achieved through a sharp reduction in the fiscal deficit and the growth of the money supply. ${ }^{90}$ As a result, inflation fell sharply (from about 100 percent in 1991 to $4 \frac{1}{2}$ percent in 1996). Also, the large overvaluation of the exchange rate, which was a principal feature of the economy during most of the 1980s was corrected with the shift to a flexible exchange rate system in 1991;

- $\quad$ Real GDP growth accelerated from an average of less than 1 percent a year during the decade of the 1980s to 7 percent during 1991-96;

- $\quad$ There was a notable improvement in health and education indicators, and the proportion of the population living in poverty fell from 67 percent in 1989 to 35 percent in 1999.

- $\quad$ On reforms, progress was made in simplifying the tax system. Also, most of the 40 public enterprises operating in 1985 were sold by 2000, and management contracts were signed for the largest - the sugar and bauxite companies. Reflecting this, public sector employment fell from the equivalent of 35 percent of the labor force in 1988 to 13 percent in 1999.

- $\quad$ Also, there was an upturn in foreign investment, mainly in the forestry, telecommunications, and mining sectors.

\footnotetext{
${ }^{88}$ The election marked the return of the PPP to government after 28 years; its longstanding leader, Cheddi Jagan, became president. The PPP won 28 of the 53 directly elected seats, and the PNC, 23.

${ }^{89}$ Egoumé-Bossogo, Faal, Nallari, and Weisman (2003).

${ }^{90}$ Central government expenditure fell from 89 percent of GDP in 1985-89 to about 40 percent in 1996-97.
} 


\section{Box 4. Selected Responses of Barbados and Guyana to the Oil Shocks, 1973-74 and 1979-80}

\begin{tabular}{|c|c|c|}
\hline $\begin{array}{l}\text { Use of the sugar } \\
\text { price windfall }\end{array}$ & $\begin{array}{l}\text { About half of the } 1973-74 \text { windfall } \\
\text { used to set up a Sugar Export Levy } \\
\text { Fund, part of which used to finance } \\
\text { low-cost housing. } 1\end{array}$ & $\begin{array}{l}\text { Much of the 1973-74 windfall used to pay for the nationalization } \\
\text { of the sugar industry and parts of the distribution sector. }\end{array}$ \\
\hline Policy response & $\begin{array}{l}\text { Initially, a slow fiscal response and } \\
\text { greater reliance on financing, but } \\
\text { by } 1978 \text {, corrective fiscal measures } \\
\text { taken. No resort to foreign } \\
\text { exchange controls. }\end{array}$ & $\begin{array}{l}\text { In 1976, response consisted of fiscal adjustment and quantitative } \\
\text { restrictions (QRs) on imports and foreign exchange. Also, a State } \\
\text { Planning Secretariat set up to monitor the large public sector and } \\
\text { the regime of controls (over bank credit, external borrowing, } \\
\text { trade, foreign exchange, prices). QRs led to scarcities of raw } \\
\text { materials, spare parts, and fuel, and electricity shortages, which } \\
\text { affected growth and inflation. Also a vibrant black market in } \\
\text { imports and foreign exchange emerged. }\end{array}$ \\
\hline $\begin{array}{l}\text { Wages and labor } \\
\text { relations }\end{array}$ & $\begin{array}{l}\text { Stable labor relations during both } \\
\text { commodity shocks. Few strikes or } \\
\text { worker protests. }\end{array}$ & $\begin{array}{l}\text { Civil service unions (which supported the government) } \\
\text { negotiated an agreement for an increase in salaries by } \\
155 \text { percent over the period 1977-79. Unions (supporting the } \\
\text { opposition) in the sugar industry and those in the bauxite sector) } \\
\text { also struck for higher wages. }\end{array}$ \\
\hline $\begin{array}{l}\text { Relations with } \\
\text { the IMF }\end{array}$ & $\begin{array}{l}\text { Recourse to IMF financing avoided } \\
\text { following the first oil shock. Fund- } \\
\text { supported program in } 1982-83 \\
\text { successfully completed. }\end{array}$ & $\begin{array}{l}1978 \text { standby arrangement completed successfully. This was } \\
\text { followed by a large loan in mid-1979 (SDR100 million, or } 400 \\
\text { percent of quota) aimed at stimulating growth by raising public } \\
\text { sector saving and investment. The objectives of the program } \\
\text { were not met, partly because of strikes and equipment } \\
\text { breakdowns in the bauxite industry that led to a worsening of the } \\
\text { fiscal and balance of payments positions. The program was } \\
\text { interrupted after a drawing of SDR } 10 \text { million. A successor loan } \\
\text { in } 1980 \text { also failed to meet its objectives, and by the end of } 1981 \\
\text { it was classified as "inoperative." Guyana began to accrue } \\
\text { arrears to the IMF in } 1983 \text { and it was declared ineligible for } \\
\text { Fund loans in } 1985 \text {. }\end{array}$ \\
\hline \multicolumn{3}{|c|}{$\begin{array}{l}1 \text { The levy yielded B } \$ 28.4 \text { million in FY } 1975 / 76 \text {, of which } \$ 14.4 \text { million was allocated to general revenues, and } \$ 14.0 \text { million } \\
\text { used to establish the Fund (Central Bank of Barbados, Annual Report 1975). } \\
{ }^{2} \text { Worrell (1987) notes that the } 1982 \text { program was based on fiscal targets determined independently by the government before } \\
\text { approaching the Fund, and that its implementation was monitored by an experienced team from the central bank and ministry of } \\
\text { finance. }\end{array}$} \\
\hline
\end{tabular}


However, the recovery ground to a halt in 1998 as tensions resurfaced after the results of the 1997 elections indicated another victory for the PPP. The opposition rejected the results on grounds of alleged fraud, and there were weeks of post-election violence and social tension. Subsequently, a settlement was negotiated by CARICOM under which the PPP agreed to embark on a comprehensive constitutional reform and hold early elections in 2001. Despite the agreement, tensions continued during 1998-2001, with another round of violence following the 2001 elections in which the PPP won the majority of seats. Once again, the elections were followed by a cycle consisting of the start of talks between the PPP and the PNC, a breakdown of these talks, more violence and demonstrations, and calls for another round of talks. ${ }^{91}$ Annual GDP growth slowed sharply to less than 1 percent in 1998-2005, and indicators of institutional quality remained weak (Figures 3-4). In the period ahead of the 2006 elections there were renewed concerns about crime and security as well as about the robustness of institutions responsible for governance and rule of law. However, the elections were conducted largely without incident.

In summary, the post-1990 period of recovery in Guyana was marked by a convergence of macroeconomic policies with those of the more successful economies in the Caribbean region, like Barbados. However, there was continued divergence in the quality of institutions, and ultimately, the recovery was not sustained. Guyana's experience with the recent cycle of crisis, recovery, and relapse into crisis is consistent in many respects with the literature about the persistence of institutions. The experience also suggests that a focus on macroeconomic policies and agendas for structural reform - while essential for economic stability and releasing donor resources - is insufficient for promoting stable growth, and that a sustained improvement in economic and social conditions will require also attention to developing and nurturing key institutions. $^{92}$

\footnotetext{
${ }^{91}$ Ryan (2003) notes that marches and demonstrations in July 2002 revealed that Guyana's economic, political, judicial, and security systems were in a state of near collapse.

${ }^{92}$ On the persistence of institutions, see Paterson (2005).
} 
Figure 3: Guyana and Barbados: Post-Independence Performance
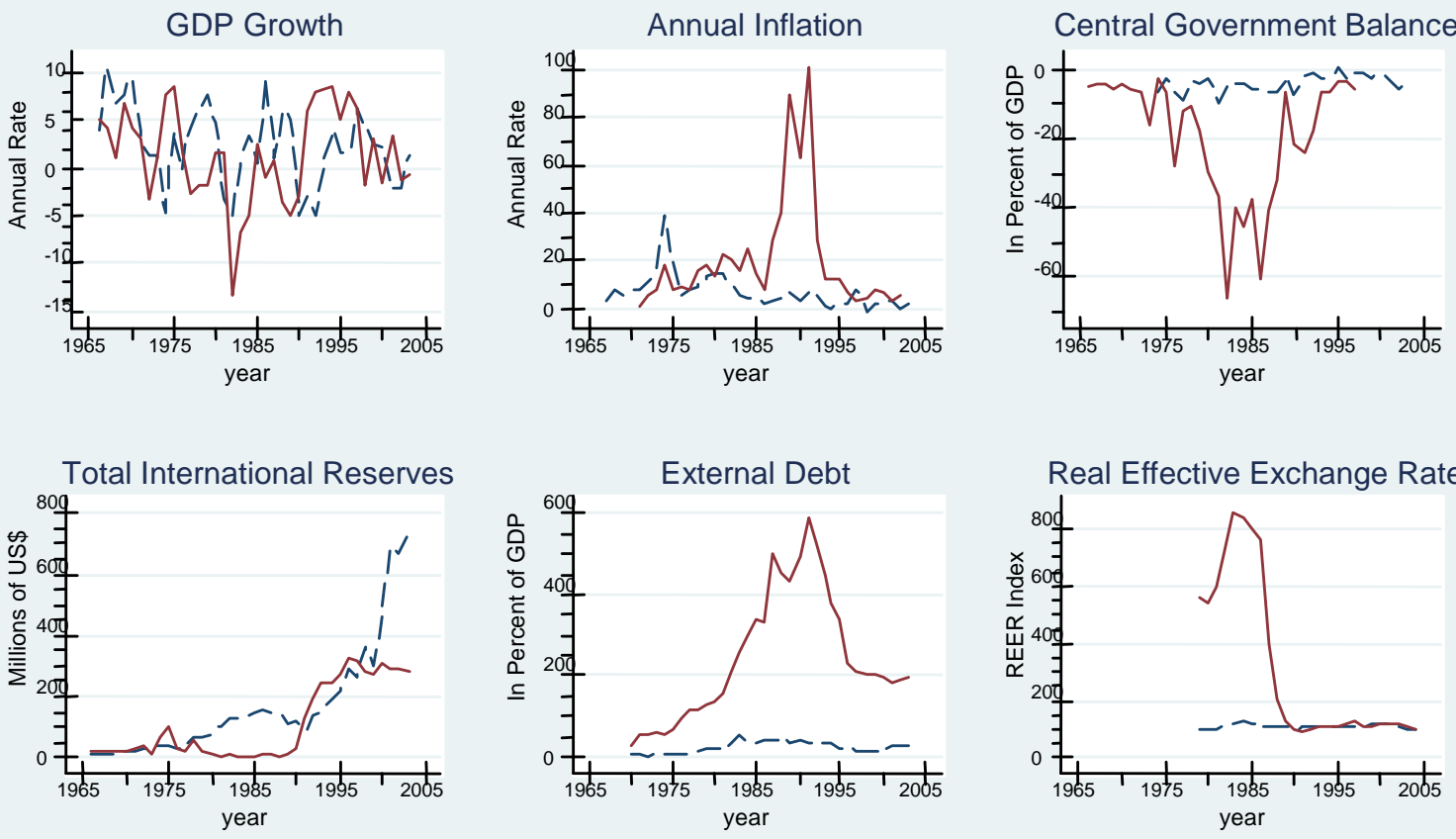

Barbados

Guyana

Sources: World Development Indicators, International Financial Statistics, and World Economic Outlook

Figure 4: Caribbean Region: Income and Institutions
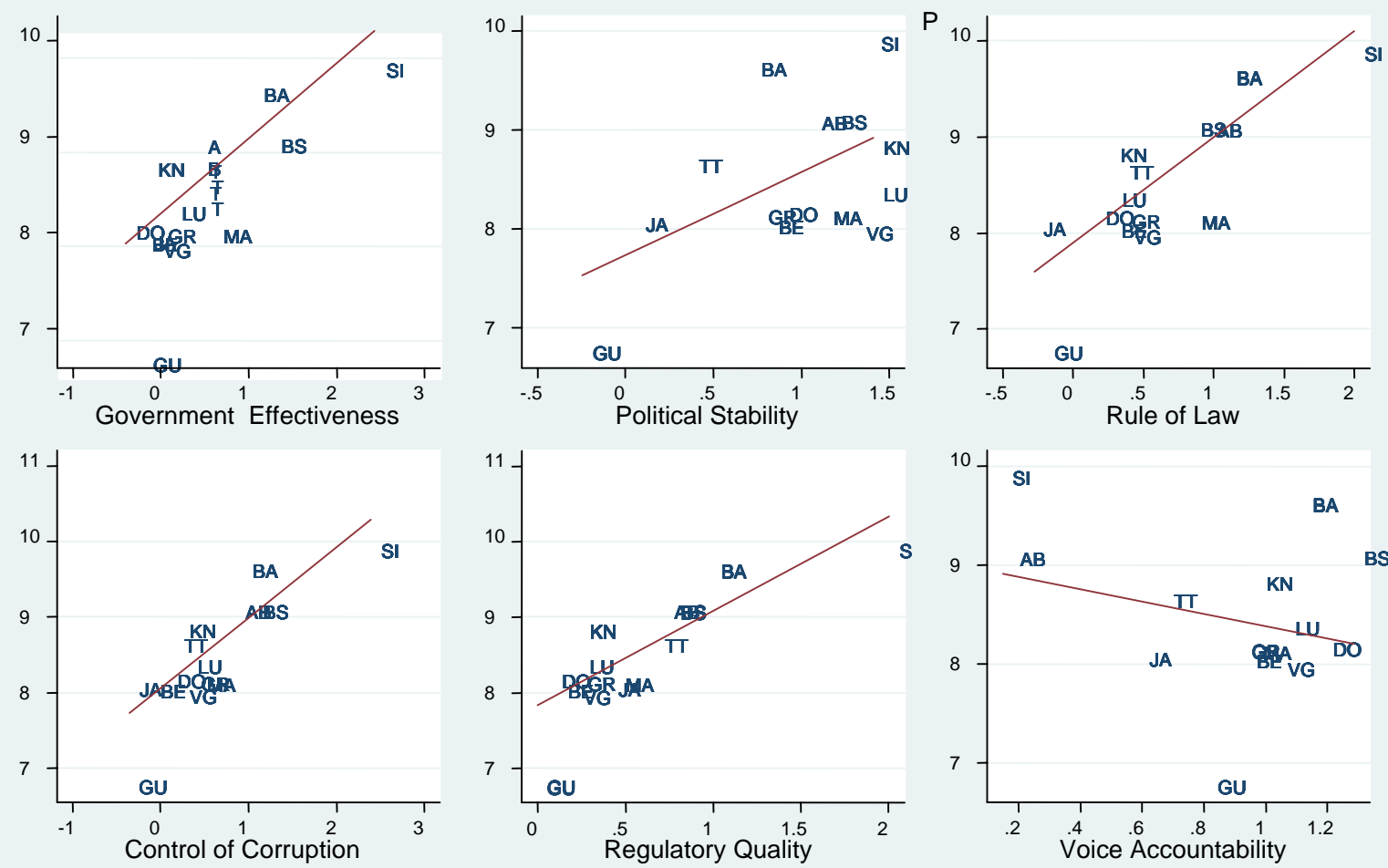

Source: World Development Indicators.

1/ Mean real per capita GDP growth covering the period 1970-2004 is measured on the vertical axis. Institutional quality measures are derived from indicators (averaged over the period 1996-2004) developed by Kaufmann, Kraay, and Mastruzzi (2005). 


\section{Conclusion}

On virtually all measures - institutional quality, incomes, human development, and povertyGuyana lags Barbados and most other former British Caribbean colonies. This paper argues that much of the origins of this divergence lies in Guyana's colonial history and its geography, which influenced the quality of the country's institutions. In particular, the separate administration of the country's three regions for about two centuries prior to unification in 1831 contributed to fragmented development and a weak sense of national cohesion. This was exacerbated by geography and difficult settlement conditions, as the priority placed by settlers on securing a satisfactory return on the heavy capital investment required for sugar cultivation in those conditions led to the development of a type of extractive state in which inadequate attention was paid to promoting sound domestic institutions. Associated with this, colonial labor and land distribution policies constrained agricultural diversification and promoted an environment of competition between the two main ethnic groups. During the colonial period, manifestations of these tensions were contained by the colonial administration. However, tensions surfaced as the colonial government withdrew, and in the absence of effective domestic institutions.

Barbados's colonial history of more than 300 years contributed to the early development of forms of representative government and well-entrenched parliamentary practices. ${ }^{93}$ Also, the island's geography contributed to relatively favorable settlement conditions, which helped promote the early development of institutions. These factors, together with small size, vulnerability to external shocks, and the absence of ethnic tensions, helped cultivate a sense of cohesion, national unity and a tradition of dialogue. Also, these characteristics and limited resources probably helped foster a propensity toward saving and fiscal discipline. The story of Guyana and Barbados, therefore, is one in which colonial history and geography contributed significantly to initial institutions and economic performance.

A large part of the economic history of Guyana is consistent with the literature on ethnic diversity, social conflict, and economic performance - with the channels leading from competition for resources among ethnic groups to rent seeking by the groups holding power. ${ }^{94}$ However, as evidenced by the experience of Mauritius, diversity stemming from colonialization is not incompatible with growth and social progress. What the experiences of Guyana and Mauritius do seem to demonstrate is that societies, and particularly ethnically diverse ones, require sound, participatory institutions that promote dialogue and inclusion, mediate conflict, and thereby avoid social and economic erosion..$^{95}$ In the absence of such institutions, efforts to

\footnotetext{
${ }^{93}$ Grier (1999) finds that colonies that were held for longer periods tend to perform better, on average, after independence.

${ }^{94}$ See Easterly and Levine (1997) and Rodrik (1999).

${ }^{95}$ For reviews of Mauritius's efforts to develop mechanisms and institutions to promote inclusion and ethnic harmony, which have contributed to the country's favorable economic performance, see Brautigam (1999), Gulhati and Nallari (1990), Rodrik (2000) and Subramanian and Roy (2001).
} 
promote growth by a focus only on conventional macro policies, structural reforms, and donor financial support are unlikely to be sustained. ${ }^{96}$

Work on strengthening institutions that promote dialogue and conflict alleviation has been taking place in Guyana. Some of this work has been supported by the Carter Center, which has stressed the need for constitutional and electoral arrangements that promote reconciliation, and for a strengthened judicial system. ${ }^{97}$ Also, the UNDP has helped support efforts toward greater social cohesion and strengthening institutions like the Ethnic Relations Commission. ${ }^{98}$ Recently, the Inter-American Development Bank (IDB) has developed projects to improve the justice system and public safety. However, given the importance to the entire region of achieving the CARICOM Single Market and Economy (CSME) and the risks to progress in this area from member countries with persistently weak institutions and economic performance, it is also essential that CARICOM continue to strengthen its institution building and conflict resolution functions as an essential feature of robust convergence mechanisms that can withstand domestic shocks in member countries. The regional body has played a key role in these areas in the past, and is likely to be among the most persuasive of the organizations involved in this area because of its community character. ${ }^{99}$

This paper forms part of the long tradition of work on exploring links between colonial history, institutions, and economic performance in the former sugar-producing British colonies in the Caribbean region. Its aim is to complement efforts to extend the framework of discussion and analysis of economic performance beyond macroeconomic policies and the degree of implementation of donor- or IMF/World Bank programs to include assessments of underlying factors and institutions. There is considerable scope for future work in this area covering, for example, both historical assessments and empirical work. Shifting the focus of analysis and discussion to how weak former colonies can learn from successful ones in the Caribbean and elsewhere about adapting their societies and institutions to achieve growth and social progress, while handling shocks, globalization, and ethnic diversity in a multi-disciplinary framework, is likely to prove most rewarding in the years ahead.

\footnotetext{
${ }^{96}$ Easterly, Ritzen and Woolcock (2006) find that where institutions are sufficiently well developed there is no adverse effect of ethnolinguistic diversity on growth.

${ }^{97}$ http://www.cartercenter.org/activities/showdoc.asp? countryID=37

${ }^{98}$ The UNDP's program for Guyana is available at http://www.undp.org.gy/\#

${ }^{99}$ As noted above, following the 1997 elections, a CARICOM team brokered an agreement between the two main political parties aimed at defusing tensions. Details of the agreement are available at http:/www.caricom.org/jsp/pressrelease/press06 98.htm
} 


\section{BIBLIOGRAPHY}

Acemoglu, D., and S. Johnson, 2002, "Institutions, Corporate Governance, and Crises" (unpublished; Cambridge, Massachusetts; Massachusetts Institute of Technology).

— and J. Robinson, 2001, "The Colonial Origins of Comparative Development: An Empirical Investigation,” American Economic Review, Vol. 91, No. 5, pp. 1369-1401.

— 2002, “An African Success Story: Botswana,” CEPR Discussion Paper No. 3219 (London: Centre for Economic Policy Research).

_ 2004, "Institutions and the Fundamental Cause of Long-Run Growth," CEPR Discussion Paper No. 4458 (London: Centre for Economic Policy Research).

— and Y. Thaicharoen, 2003, "Institutional Causes, Macroeconomic Symptoms: Volatility, Crises and Growth,” Journal of Monetary Economics, Vol. 50, pp. 49-123.

Alesina, A., A. Devleeschauwer, W. Easterly, S. Kurlat, and R. Wacziarg, 2003, "Fractionalization," Journal of Economic Growth, Vol. 8, No. 2, pp. 155-94.

Alesina, A., and E. La Ferrara, 2005, "Ethnic Diversity and Economic Performance," Journal of Economic Literature, Vol. 53, pp. 762-800.

Ayearst, M., 1960, The British West Indies (New York: New York University Press).

Beckford, G. (ed), 1975, Caribbean Economy: Dependence and Backwardness (Mona, Jamaica: Institute of Social and Economic Research, University of the West Indies).

Beckles, H and V. Shepherd (eds), 1996, Caribbean Freedom: Economy and Society from Emancipation to the Present (Princeton: Markus Wiener Publishers).

Blackman, C., 1989, "Two Lost Decades in Caribbean Economic History," Caribbean Affairs, Vol. 2, pp. 92-108.

—, 1998, “The Barbados Model,” Caribbean Affairs, Vol. 8, No. 1, pp. 61-68.

Bourne, C., 1975, “The Plantation Economy of Guyana-Review Article," Social and Economic Studies, Vol. 24, No. 4

Brautigam, D., 1999, “The Mauritius Miracle: Democracy, Institutions, and Economic Policy,” in "State, Conflict, and Democracy in Africa" ed. by R. Joseph (Colorado; Lynne Rienner Publishers).

Cumper, G.E., (ed), 1960, The Economy of the West Indies, (Mona, Jamaica: Institute of Social and Economic Research, University of the West Indies). 
Cumpston, I. M., 1956, “A Survey of Indian Immigration to British Tropical Colonies to 1910," Population Studies, Vol. 10, No. 2, pp.158-165.

Daly, V. T., 1975, A Short History of the Guyanese People (London: Macmillan).

De Caires D., 1988, Guyana After Burnham: A New Era?, Caribbean Affairs, Vol. 1, No. 1, pp. 183-198.

Demas, W. G., 1976, Essays on Caribbean Integration and Development (Mona, Jamaica: Institute of Social and Economic Research, University of the West Indies).

Dominguez, J., and D. Worrell (eds), 1993, Democracy in the Caribbean (Baltimore: Johns Hopkins Press).

Downes, A.S., and L. Nurse, 2004, "Macroeconomic Management and Building Social Consensus: An Evaluation of the Barbados Protocols," Journal of Eastern Caribbean Studies, Vol. 29, No. 4.

Downes, A., 2001, "Economic Growth and Development in Barbados during the Twentieth Century," Integration and Trade, Vol. 15, No. 5, pp. 145-176.

Dunn, R. S., 1969, 'The Barbados Census of 1680: Profile of the Richest Colony in English America," The William and Mary Quarterly, $3^{\text {rd }}$ Ser., Vol. 26, No. 1. pp. 3-30.

Easterly, W., J. Ritzen, and M. Woolcock, 2006, "Social Cohesion, Institutions, and Growth," Economics and Politics, Vol. 18, No. 2. pp. 103-120.

Easterly, W., and R. Levine, 2003, “Tropics, Germs, and Crops: How Endowments Influence Economic Development," Journal of Monetary Economics, Vol 50, pp. 3-39.

Easterly, W., and R. Levine, 1997, "Africa's Growth Tragedy: Policies and Ethnic Divisions," Quarterly Journal of Economics, Vol. 111, No. 4, pp. 1203-1250.

Egoumé-Bossogo, P., E. Faal, R. Nallari, E. Weisman, 2003, Guyana: Experience with Macroeconomic Stabilization, Structural Adjustment, and Poverty Reduction (Washington: International Monetary Fund).

Engerman, S. L., 1982, "Economic Adjustments to Emancipation in the United States and British West Indies,” Journal of Interdisciplinary History, Vol. 13, No. 2, pp. 191-220. , and K. Sokoloff, 2003, "Institutional and Non-Institutional Explanations of Economic Differences," NBER Working Paper No. 9989, (Massachusetts: National Bureau of Economic Research).

— , 2005, "Colonialism, Inequality, and Long-Run Paths of Development," NBER Working Paper No. 11057 (Massachusetts: National Bureau of Economic Research). 
Eriksen, T. H., 1994, "Nationalism, Mauritian Style: Cultural Unity and Ethnic Diversity," Comparative Studies in Society and History, Vol. 36, No. 3, pp. 549-574.

Faal, E., 2003, "Currency Demand, the Underground Economy, and Tax Evasion: The Case of Guyana,” IMF Working Paper 03/07 (Washington: International Monetary Fund).

Fashoyin, T., 2004, “Tripartite Cooperation, Social Dialogue and National Development," International Labour Review, Vol. 143, No. 4, pp. 341-371.

Frankel, J. A., N. Birdsall, J. Sachs, and G. Ortiz, 2003, "Panel Discussion-Promoting Better National Institutions: The Role of the IMF," IMF Staff Papers, Vol. 50, Special Issue, IMF Third Annual Research Conference.

Galenson, D., 1985, "Population Turnover in the English West Indies in the Late Seventeenth Century: A Comparative Perspective," The Journal of Economic History, Vol. 45, No. 2, pp. 227-235.

Glaeser, E., R. La Porta, F. Lopez-de-Silanes, and A. Shleifer, 2004, "Do Institutions Cause Growth?," NBER Working Paper No. 10568, (Massachusetts: National Bureau of Economic Research).

Glasgow, R.A., 1970, Guyana: Race and Politics among Africans and East Indians, (The Hague: Martinus Nijhoff).

Gokcekus, O, N. Manning, R. Mukherjee, and R. Nallari, 2001, "Institutional Environment and Public Officials' Performance in Guyana," World Bank Technical Paper No. 506 (Washington: The World Bank).

Government of Barbados, 1948, A Ten Year Development Plan for Barbados (Bridgetown).

Government of Guyana, 1966, Economic Survey of Guyana (Georgetown: Government Statistical Bureau).

Green, W. A.., 1997, “Caribbean Historiography, 1600-1900: The Recent Tide,” Journal of Interdisciplinary History, Vol. 7, No. 3. pp. 509-530.

Greene, J., 1988, Pursuits of Happiness-The Social Development of Early Modern British Colonies and the Formation of American Culture (Chapel Hill: The University of North Carolina Press).

Greenfield, S., 1969, "Slavery and Plantation in the New World: the Development and Diffusion of a Social Form," Journal of Inter-American Studies, Vol. 11, No. 1, pp. 44-57.

Grier, R., 1999, “Colonial Legacies and Economic Growth,” Public Choice, Vol. 98, pp. 317-335.

Griffith, W. H., 2002, “A Tale of Four CARICOM Countries,” Journal of Economic Issues, Vol. 36. No. 1. 
Gulhati, R., and R. Nallari, 1990, Successful Stabilization and Recovery in Mauritius (Washington: The World Bank).

Hammond, S. A., 1946, "Education in the West Indies," The Journal of Negro Education, Vol. 15, No. 3, pp. 427-449.

Harewood, J., 1975, "West Indian People," in Caribbean Economy: Dependence and Backwardness, ed. by G. Beckford (Mona, Jamaica: Institute of Social and Economic Research, University of the West Indies).

Hilaire, A.,. 2000, "Caribbean Approaches to Stabilization,” IMF Working Paper 00/73 (Washington: International Monetary Fund).

Hintzen, P.C., 1981, “Capitalism, Socialism, and Socio-Political Confrontation in Multiracial Developing States: A Comparison of Guyana and Trinidad" (Ph.D. dissertation; New Haven, Connecticut: Yale University).

Hughes, C., 1953, "Semi-Responsible Government in the British West Indies," Political Science Quarterly, Vol. 68, No. 3, pp. 338-353.

Jagan, C., 1972, The West on Trial (Berlin: Seven Seas Publishers).

Kaufmann, D., A. Kraay, and M. Mastruzzi, 2005, “Governance Matters IV: Governance Indicators for 1996-2004” (unpublished; Washington: The World Bank).

Knack, S., and P. Keefer, 1995, "Institutions and Economic Performance: Cross-Country Tests Using Alternative Institutional Measures,” Economics and Politics, Vol. 7, No. 3, pp. 207-227.

Knight, F., 1990, The Caribbean-The Genesis of a Fragmented Nationalism (New York: Oxford University Press).

Kupperman, K., 1984, "Fear of Hot Climates in the Anglo-American Colonial Experience," William and Mary Quarterly, $3^{\text {rd }}$ Ser. Vol. 41, pp. 213-240.

Lewis, A., 1955, The Theory of Economic Growth (London: George Allen and Unwin).

Lewis, A., 1969, Aspects of Tropical Trade: 1883-1965, Wicksell Lecture (Stockholm: Almqvist \& Wiksell) 1969.

Lewis, G. K., 1968, The Growth of the Modern West Indies (London: Macgibbon and Kee).

Mandle, J., 1996, Persistent Underdevelopment_Change and Economic Modernization in the West Indies, (The Netherlands: Gordon and Breach).

Mars, P., 2001, "Ethnic Politics, Mediation, and Conflict Resolution: The Guyana Experience," Journal of Peace Research, Vol. 38, No. 3, pp. 353-372. 
Marshall, D., 1998, Caribbean Political Economy at the Crossroads (London: Macmillan).

Mintz, S., 1984, "Labor Needs and Ethnic Ripening in the Caribbean Region," Washington: The Wilson Center Working Paper No. 137 (Washington: The Wilson Center).

Mishra, P., 2006, "Emigration and the Brain Drain: Evidence from the Caribbean," IMF Working Paper 06/25 (Washington: International Monetary Fund).

Moohr, M., 1972, “The Economic Impact of Slave Emancipation in British Guiana, 1832-1852, " The Economic History Review, New Series, Vol. 25, No. 4, pp. 588-607.

Odle, M., 1975, "Public Policy," in Caribbean Economy: Dependence and Backwardness, ed. by G. Beckford (Mona, Jamaica: Institute of Social and Economic Research, University of the West Indies).

Paterson, B., 2005, "Institutions: Why Are They Persistent, and Why Do They Change?" (unpublished; Kingston: Queen's University).

Payne, A., 1981, "Change in the Commonwealth Caribbean", Chatham House Paper No.12, (London: The Royal Institute of International Affairs).

Proctor, R., 1980, “Early Developments in Barbadian Education,” The Journal of Negro Education, Vol. 49, No. 2, pp. 184-195.

Rajan, R.G. and L. Zingales, 2005, "The Persistence of Underdevelopment: Institutions, Human Capital, or Constituencies?" (unpublished; Washington: International Monetary Fund).

Roberts, G., 1960, "Movements in Population and the Labour Force," in The Economy of the West Indies, ed. by G. Cumper (Jamaica: Institute of Social and Economic Research, University of the West Indies).

Rodney, W., 1981, “A History of the Guyanese Working People, 1881-1905,” (Baltimore: The Johns Hopkins University Press).

Rodrik, D., 1999, "Where Did All the Growth Go? External Shocks, Social Conflict, and Growth Collapses," Journal of Economic Growth, Vol. 4, pp. 385-412.

_ 2000, "Institutions for High-Quality Growth: What They Are and How to Acquire Them,” NBER Working Paper No. 7540 (Massachusetts: National Bureau of Economic Research).

A. Subramanian, and F. Trebbi, 2002, "Institutions Rule: the Primacy of Institutions over Integration and Geography in Economic Development," IMF Working Paper 02/189 (Washington: International Monetary Fund). 
Ryan, S., 1993, "Structural Adjustment and the Ethnic Factor" in Democracy in the Caribbean, ed. by J. Dominguez, R. Pastor, and D. Worrell (Baltimore: Johns Hopkins University Press).

— 2003, "Majoritarian and Consociational Systems of Governance: Paradigms of Conflict," in "Governance in the Age of Globalization-Caribbean Perspectives," ed. by Denis Benn and Kenneth Hall (Kingston: Ian Randle Publishers).

Sachs, J., 2001, “Tropical Underdevelopment,” NBER Working Paper No. 8119 (Massachusetts: National Bureau of Economic Research).

Sachs, J., 2003, "Institutions Don't Rule: Direct Effects of Geography on Per Capita Income," NBER Working Paper No. 9490 (Massachusetts: National Bureau of Economic Research).

Shepherd, C., 1929, "The Sugar Industry in the British West Indies and British Guiana with Special Reference to Trinidad," Economic Geography, Vol. 5, No. 2, pp. 149-175.

Sires, R., 1954, "British Guiana: The Suspension of the Constitution," The Western Political Quarterly, Vol. 7, No. 4, pp. 554-569.

Sokoloff, K., and S. Engerman, S., 2000, "Institutions, factor endowments, and paths of development in the new world," Journal of Economic Perspectives, Vol.14, pp. 217-232.

Standing, G., 1979, "Semi-Feudalism, Migration and the State in Guyana," Research Working Paper No. 73, World Employment Programme (Geneva: International Labor Organization).

Staritz, C., J. Gold, and R. Atoyan, 2005, “Guyana: Why Has Growth Stopped? An Empirical Study on the Stagnation of Economic Growth," (unpublished; Washington: International Monetary Fund).

Statistics Office of the West Indies Federation, 1960, National Income Statistics (Bridgetown: Government Printing Office).

Subramanian, A., and D. Roy, 2001, "Who Can Explain the Mauritian Miracle: Meade, Romer, Sachs, or Rodrik?” IMF Working Paper 01/116 (Washington: International Monetary Fund).

Thomas, C.Y., 1984, Plantations, Peasants, and State-A Study of the Mode of Sugar Production in Guyana, (Kingston: Institute for Social and Economic Research, University of the West Indies).

Tomasek, R., 1959, "British Guiana: A Case Study of British Colonial Policy," Political Science Quarterly, Vol. 74, No. 3. pp. 393-411.

U.K. Colonial Office, 1965: Barbados: Review of 1962 and 1963 (Bridgetown: Government Printing Office). 
West India Royal Commission, 1945, Report of the Commission (London: Her Majesty's Stationery Office).

Williams, E., 1945, “The Historical Background of British Guiana's Problems,” Journal of Negro History, Vol. 30, No. 4, pp. 357-381.

— 1984, From Columbus to Castro-The History of the Caribbean (New York: Vintage Books).

Wong, D.C., 1984, “A Review of Caribbean Political Economy," Latin American Perspectives, Vol. 11, No. 3.

World Bank, 1953, The Economic Development of British Guiana (Baltimore: The Johns Hopkins University Press).

World Bank, 1993, Guyana: From Economic Recovery to Sustained Growth (Washington: The World Bank).

Worrell, D., (ed), 1982, The Economy of Barbados, 1946-1980 (Bridgetown: Central Bank of Barbados).

— 1987, Small Island Economies: Structure and Performance of the English Speaking Caribbean Since 1970 (New York: Praeger).

— 1993, "The Economies of the English-speaking Caribbean since 1960," in Democracy in the Caribbean, ed. by Dominguez, J., R. Pastor, and D. Worrell (Baltimore: The Johns Hopkins University Press).

- H. Codrington, R. Craigwell, and K. Greenidge, 2003: "Economic Resilience with an Exchange Rate Peg: The Barbados Experience, 1985-2000," IMF Working Paper 03/168 (Washington: International Monetary Fund). 